\title{
Spatially resolved soil solution chemistry in a central European atmospherically polluted high-elevation catchment
}

\author{
Daniel A. Petrash ${ }^{1}$, Frantisek Buzek ${ }^{1}$, Martin Novak ${ }^{1}$, Bohuslava Cejkova ${ }^{1}$, Pavel Kram ${ }^{1}$, \\ Tomas Chuman $^{1}$, Jan Curik ${ }^{1}$, Frantisek Veselovsky ${ }^{2}$, Marketa Stepanova ${ }^{1}$, Oldrich Myska ${ }^{1}$, \\ Pavla Holeckova $^{1}$, and Leona Bohdalkova ${ }^{1}$ \\ ${ }^{1}$ Czech Geological Survey, Department of Environmental Geochemistry and Biogeochemistry, Geologicka 6, \\ 152 00, Prague 5, Czech Republic \\ ${ }^{2}$ Czech Geological Survey, Department of Rock Geochemistry, Geologicka 6, \\ 152 00, Prague 5, Czech Republic
}

Correspondence: Daniel A. Petrash (daniel.petras@geology.cz)

Received: 4 March 2019 - Discussion started: 2 April 2019

Revised: 3 July 2019 - Accepted: 7 July 2019 - Published: 31 July 2019

\begin{abstract}
We collected soil solutions by suction lysimeters in a central European temperate forest with a history of acidification-related spruce die-back in order to interpret spatial patterns of soil nutrient partitioning, compare them with stream water chemistry and evaluate these parameters relative to concurrent loads of anions and cations in precipitation. Five lysimeter nests were installed in the $33 \mathrm{ha} \mathrm{U}$ dvou loucek (UDL) mountain catchment at different topographic positions (hilltops, slopes and valley). Following equilibration, monthly soil solution samples were interrogated over a 2-year period with regard to their $\mathrm{SO}_{4}^{2-}, \mathrm{NO}_{3}^{-}, \mathrm{NH}_{4}^{+}, \mathrm{Na}^{+}, \mathrm{K}^{+}, \mathrm{Ca}^{2+}$, $\mathrm{Mg}^{2+}$ and total dissolved $\mathrm{Al}$ concentrations, organic carbon (DOC) and $\mathrm{pH}$. Soil pits were excavated in the vicinity of each lysimeter nest to also constrain soil chemistry. For an estimation of phosphorus (P) availability, ammonium oxalate extraction of soil samples was performed. Cation exchange capacity (CEC $\leq 58 \mathrm{meq} \mathrm{kg}^{-1}$ ) and base saturation (BS $\leq 13 \%$ ) were found to be significantly lower at UDL than in other monitored central European small catchments areas. Spatial trends and seasonality in soil solution chemistry support belowground inputs from mineral-stabilized legacy pollutants. Overall, the soil solution data suggest that the ecosystem was still chemically out of balance relative to the concurrent loads of anions and cations in precipitation, documenting incomplete recovery from acidification. Nearly 30 years after peak acidification, UDL exhibited similar soil solution concentrations of $\mathrm{SO}_{4}^{2}, \mathrm{Ca}^{2+}$ and $\mathrm{Mg}^{2+}$ as median values at the Pan-European International Co-operative Program (ICP) Forest sites with similar bedrock lithology and vegetation cover, yet $\mathrm{NO}_{3}^{-}$concentrations were an order of magnitude higher. When concentrations of $\mathrm{SO}_{4}^{2-}, \mathrm{NO}_{3}^{-}$and base cations in runoff are compared to soil pore waters, higher concentration in runoff points to lateral surficial leaching of pollutants and nutrients in excess than from topsoil to subsoil. With $\mathrm{P}$ availability being below the lowest range observed in soil plots from the Czech Republic, the managed forest ecosystem in UDL probably reflects growing inputs of $\mathrm{C}$ from regenerating vegetation in the $\mathrm{N}$-saturated soil, which leads to $\mathrm{P}$ depletion in the soil. In addition, the observed spatial variability provides evidence pointing to substrate variability, $\mathrm{C}$ and $\mathrm{P}$ bioavailability, and landscape as major controls over base metal leaching toward the subsoil level in $\mathrm{N}$-saturated catchments.
\end{abstract}




\section{Introduction}

During the second half of the 20th century, atmospheric deposition of reactive nitrogen $(\mathrm{N})$ and sulfate $\left(\mathrm{SO}_{4}^{2-}\right)$ caused persistent perturbations in temperate forest soils and watersheds across Europe (Blazkova, 1996; Alewell, 2001; Verstraeten et al., 2017). Reaction of sulfur dioxide $\left(\mathrm{SO}_{2}\right)$ and nitrogen oxides $\left(\mathrm{NO}_{x}\right)$ with water molecules in the atmosphere produced sulfuric and nitric acids $\left(\mathrm{H}_{2} \mathrm{SO}_{4}, \mathrm{HNO}_{3}\right)$ which then entered mountain forest ecosystems via wet and dry deposition. Intergovernmental cooperation to significantly abate detrimental emissions was implemented during the 1980s and resulted in a decrease in the atmospheric deposition of soil-acidifying species. Industry restructuring and installation of scrubbers in power plants significantly reduced industrial $\mathrm{SO}_{2}$ emission rates by more than $90 \%$ in one of the most polluted industrial regions of central Europe, known as the "Black Triangle", which includes mountainous border regions of three countries: Czech Republic, East Germany, and Poland (Fig. 1a; Blazkova, 1996; Novak et al., 2005). A decrease in soil solution $\mathrm{SO}_{4}^{2-}$ concentrations followed, and has progressively lowered soil solution ionic strengths while contributing to a progressive raise in soil $\mathrm{pH}$, which may have in turn increased organic matter leaching by lowering the soil solution concentrations of aluminum ions $\left(\mathrm{Al}^{3+}\right)$ (e.g., Monteith et al., 2007).

Although also significantly decreased, atmospheric inputs of reactive $\mathrm{N}$ species in excess to the nutritional demands of plants and microorganisms have prevailed (Waldner et al., 2014, 2015). These have resulted in forest ecosystem perturbations consisting of a cascade of biogeochemical reactions linked to soil $\mathrm{N}$ saturation (Galloway et al., 2003). For instance, despite a $>50 \%$ reduction in atmospheric $\mathrm{N}$ inputs (Kopacek et al., 2015), in the Czech Republic alone the value of the total nitrogen deposition remained during the last decade in the range of $70000-80000 \mathrm{t} \mathrm{yr}^{-1}$ as a result of the production of $\mathrm{NO}_{x}$ emissions from transport, industrial production and energy generation (CENIA, 2017). The unchanged figures despite significant efforts for controlling industrial emissions over the same period is a societal concern since there is growing uncertainty on whether or not central European temperate forest ecosystems will have the capacity to continue acting as major sinks for a $15 \%-20 \%$ intensification in anthropogenic emissions of reactive $\mathrm{N}$ to the atmosphere (Galloway et al., 2008). A detrimental effect of unmanaged soil $\mathrm{N}$ saturation in catchment areas is the propagation of environmental effects to nearby lacustrine ecosystems (Kopacek et al., 1995).

$\mathrm{N}$ saturation in soils is indicated by leaching and losses of nitrate $\left(\mathrm{NO}_{3}^{-}\right.$) below the rooting zone (Aber et al., 1989; Perakis and Hedin, 2002). Continuing mineralization of soil organic $\mathrm{N}$ pools has been pointed out as the most probable reason for high $\mathrm{N}$ fluxes. Yet, the fate of excess $\mathrm{NO}_{3}^{-}$is not only controlled by belowground biogeochemical $\mathrm{N}$-cycling and remineralization processes, but also by site-specific charac-

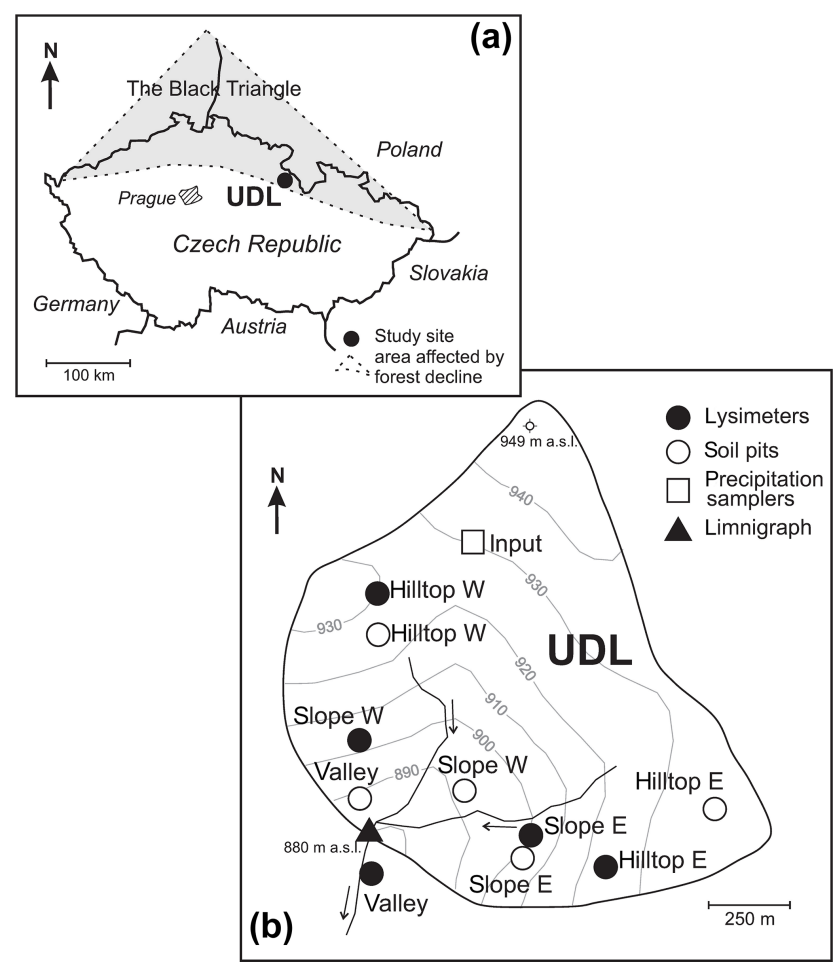

Figure 1. Study site location: (a) the shaded area shows the socalled "Black Triangle". (b) Sampling setup.

teristics such as the size and quality of subsoil carbon pools, bedrock lithology, differential weathering and hydrological conditions (Lovett and Goodale, 2011). Altogether these parameters affect soil solution chemistries to produce complex spatial and temporal trends at a catchment scale.

Given the number of interacting factors affecting soil solution chemistries, there is an intrinsic difficulty associated with interpreting soil solution datasets. However, the chemical composition of soil solutions has been proven useful to assess the mobility of anionic species and nutrients in soils and their leaching from soil profiles (Nieminen et al., 2016). It is thought to be reflective of the equilibrium between atmospheric deposition and soil physicochemical processes, including mineral weathering, sorption-desorption and cation exchange, as well as biological processes such as remineralization and nutrient turnover (Smith, 1976; Scott and Rothstein, 2014). In consequence, soil solution chemistries are increasingly seen as valuable indicators of perturbed forest ecosystems (Nieminen et al., 2016; Verstraeten et al., 2017).

Here, we interpret temporal and spatial relations between environmentally relevant chemical species in soil solutions collected using nests of lysimeters in a small, central European high-elevation catchment $\mathrm{U}$ dvou loucek (UDL) that formerly received high loads of atmospheric pollutants which resulted in soil acidification and spruce die-back. Some 30 years after peak acidification, the soil solutions at UDL were collected across an elevation gradient during a 2-year 
evaluation period. We revisited the unpublished chemical records to (i) evaluate how they reflect concurrent atmospheric deposition trends and stream water fluxes of acidifying species and base cations (following Oulehle et al., 2017), and to what extent seasonal shifts observed on atmospheric deposition trends affected the spatially and temporally variable base cation contents of the independently measured soil solution chemistries; (ii) determine the effects of variable base cation content of soil solutions, soil granulometry and aluminum contents over the belowground carbon (C) and phosphorus (P) allocation; and (iii) assess to what extent the chemistry of soil solutions varies along the topographic gradient. Our small catchment has a low pedodiversity as it is situated entirely on base-poor gneissic bedrock in the northeastern part of the Czech Republic (Fig. 1a). This peculiarity simplifies our interpretations (cf. Kram et al., 2012). In addition, the contribution of groundwater vs. runoff infiltration is further evaluated by means of a supplementary isotopic runoff model, which provides evidence for a likely contribution of groundwater enriched in selected chemical species due to sufficiently long water-saprolite interactions.

Amongst 14 multi-decadal monitored small forested catchments of the Czech GEOMON network, UDL received the highest bulk atmospheric loads of a nitrogen and sulfur. As a result, the catchment is $\mathrm{P}$ limited and purportedly $\mathrm{N}$ saturated, with the ongoing pollution recovery process apparently altering concentrations and surface fluxes of other solutes via runoff (Oulehle et al., 2017). This paper primarily addresses soil solutions chemistry in the UDL catchment. Supporting data on the chemistry of spruce canopy throughfall and stream runoff parameters, which are used here for comparison purposes, are accessible in Oulehle et al. (2017). The combined dataset documents spatial heterogeneity of soil solutions in the form of variable nutrient imbalances and offers further information to improve interpretations on the dynamics and catchment-scale patterns of soil solutions in temperate forests undergoing recovery after peak acidification.

\section{Study site and background information}

This study was conducted in the UDL catchment, northeastern Bohemia, Czech Republic. Located in the Eagle Mountains (Orlické hory) at coordinates $50^{\circ} 13^{\prime} \mathrm{N}$, $16^{\circ} 29^{\prime} \mathrm{E}$ (Fig. 1a), UDL is a $33 \mathrm{ha}, \mathrm{V}$-shaped valley with a medium-gradient sloping land (Fig. 1b) incised within orthogneiss $\left(\mathrm{SiO}_{2}=75 \mathrm{wt} \% ; \mathrm{Na}_{2} \mathrm{O}+\mathrm{K}_{2} \mathrm{O}=8 \mathrm{wt} \% ; \mathrm{MgO}+\right.$ $\mathrm{CaO}<0.5 \mathrm{wt} \%)$. This acid metamorphic lithology comprises the Orlica-Snieznik Massif of Cambro-Ordovician age, together with blue schists of Neoproterozoic sedimentary protoliths that were intruded by a granitic protolith (Winchester et al., 2002; Don et al., 2003). A detailed description of the soils occurring in this watershed has been previously reported (Novak et al., 2005; Oulehle et al., 2017). Accord- ingly, the soils in the catchment are mostly acidic Podzols developed on orthogneiss to which only the Entic qualifier applies. Low base status soils have developed at the expense of the mineralogy of the orthogneissic bedrock, and given the lack of lithological discontinuities, pedodiversity is low across the catchment area, with Mor being the most common humus.

With an elevation of $880-950 \mathrm{~m}$ a.s.l., UDL's climate is characterized as humid temperate. The mean precipitation is $1500 \mathrm{~mm} \mathrm{yr}^{-1}$ and the mean annual air temperature is $5^{\circ} \mathrm{C}$. An ephemeral snow cover lasts from late November to late March, when the highest monthly stream water runoff flow is usually recorded $(\sim 162 \pm 29 \mathrm{~mm})$. Vegetation cover complexity is low and essentially consist in Norway spruce (Picea abies, L. Karst). Following reforestation, UDL's vegetation cover includes approximately $27 \%$ of trees $<40$ years in age, with $\sim 5 \%$ (1.7 out of 33 ha) remaining non-forested.

Historically, the site was influenced by emissions from nearby large industrial complexes. From the early 1970s, high anthropogenic discharges of $\mathrm{SO}_{2}$ and $\mathrm{NO}_{x}$ produced $\mathrm{H}_{2} \mathrm{SO}_{4}$ and $\mathrm{HNO}_{3}$ that affected the temperate forest ecosystem via wet and dry deposition. The largest point sources of these compounds were coal-burning power plants (Blazkova, 1996; Kolar et al., 2015). In central Europe alone, acid rain killed spruce stands over an area of approximately $1000 \mathrm{~km}^{2}$ in the so-called "Black Triangle" (Novak et al., 2005). Emissions of acidifying compounds in these centrally planned economies peaked in the late 1980s; installation of desulfurization units in coal-burning power plants started in 1987 and was completed in the mid-1990s in both the Czech Republic and Germany, and several years later in southern Poland (Alewell, 2001; Hruška and Krám, 2003; Novak et al., 2005).

As in other coniferous forest ecosystems negatively affected by acid rain, in the Black Triangle area the productivity of temperate forests was likely perturbed by (i) enhanced leaching of base cations, such as potassium $\left(\mathrm{K}^{+}\right)$, calcium $\left(\mathrm{Ca}^{2+}\right)$ and magnesium $\left(\mathrm{Mg}^{2+}\right)$ (e.g., Gundersen et al., 2006), and (ii) decreased bioavailability of phosphorous (P) (Gradowski and Thomas, 2008). UDL is also one of only three monitored catchments in the Czech Republic at elevations $>700 \mathrm{~m}$ a.s.l. whose forests were also affected between approximately 1975 and 1996 by massive acidification-related spruce die-back. After spruce defoliation, liming by aircraft was performed three times to raise the soil pH. Liming took place in 1986, 2002 and 2007, introducing three metric tons of ground dolomitic limestone per hectare into the mountain ecosystem on each occasion (Jakub Hruska, personal communication, 2018). Accordingly, during the decade 1994-2014, the median $\mathrm{pH}$ in the stream water remained stable in the range $5.2 \pm 0.4$, while over the same period, median $\mathrm{pH}$ levels measured in water percolating through the canopy (i.e., throughfall) increased from 4.1 to 5.2 (Oulehle et al., 2017).

Historical input-output hydrochemical data are summarized in Table 1, and time-series concentration data for base 
Table 1. Average hydrochemical data 2012-2013 (following Oulehle et al., 2017).

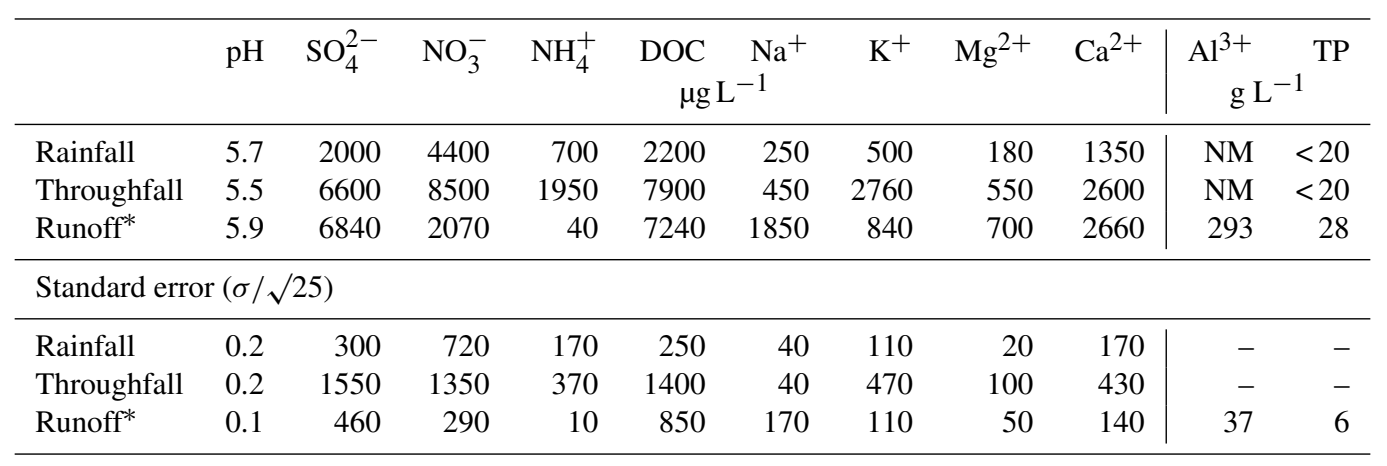

* Average runoff flux during the monitoring period was $9.4 \mathrm{Ls}^{-1}$, with maximums recorded in April $\left(76.9 \pm 4.0 \mathrm{~L} \mathrm{~s}^{-1}\right)$ and minimums in August $\left(0.5 \pm 0.1 \mathrm{~L} \mathrm{~s}^{-1}\right)$. NM: not measured.

cations $\left(\mathrm{Ca}^{2+}, \mathrm{Mg}^{2+}, \mathrm{K}^{+}, \mathrm{Na}^{+}\right)$, nitrate $\left(\mathrm{NO}_{3}^{-}\right)$, and sulfate $\left(\mathrm{SO}_{4}^{2-}\right)$ are shown in Fig. 2. According to Oulehle et al. (2017), UDL stream's pH was consistently acidic $(<5.5)$ during the studied period. For most elements (except for $\mathrm{Na}^{+}$), the highest concentrations were observed in spruce canopy throughfall, followed by stream water $\left(\mathrm{SO}_{4}^{2-}, \mathrm{Ca}^{2+}\right.$, $\left.\mathrm{Mg}^{2+}, \mathrm{K}^{+}\right)$and open-area precipitation $\left(\mathrm{NO}_{3}^{-}\right)$. The median (1994-2014) sulfur (S) bulk atmospheric input was $\sim 1.6 \mathrm{~g} \mathrm{~m}^{-2} \mathrm{yr}^{-1}$, which is far in excess of the atmospheric inputs observed in the remaining 13 GEOMON-monitored catchments across the Czech Republic $\left(0.75 \mathrm{~g} \mathrm{~m}^{-2} \mathrm{yr}^{-1}\right)$. Dissolved inorganic nitrogen (DIN) deposition input was $11.7 \mathrm{~g} \mathrm{~m}^{-2} \mathrm{yr}^{-1}$, thus exceeding the value observed at other monitored sites. The $\mathrm{Ca}^{2+}$ input of $2.5 \mathrm{~g} \mathrm{~m}^{-2} \mathrm{yr}^{-1}$ largely exceeded the average $\mathrm{Ca}^{2+}$ input into other monitored catchments $\left(0.6 \mathrm{~g} \mathrm{~m}^{-2} \mathrm{yr}^{-1}\right)$. The $\mathrm{Mg}^{2+}$ catchment input into UDL was $0.3 \mathrm{~g} \mathrm{~m}^{-2} \mathrm{yr}^{-1}$ (the median for all sites of the monitoring network was $0.1 \mathrm{~g} \mathrm{~m}^{-2} \mathrm{yr}^{-1}$ ). Inputs of $\mathrm{Na}^{+}$and $\mathrm{K}^{+}$ were 0.6 and $1.3 \mathrm{~g} \mathrm{~m}^{-2} \mathrm{yr}^{-1}$, respectively (averages across GEOMON sites were 0.2 and $0.5 \mathrm{~g} \mathrm{~m}^{-2} \mathrm{yr}^{-1}$ ).

\section{Materials and methods}

\subsection{Soil solution samples}

In October 2010, five nests of Prenart suction lysimeters were installed at $50 \mathrm{~cm}$ depth below the soil surface in a V-shaped arrangement as follows: hilltop west, hilltop east, slope west, slope east, and valley (filled circles in Fig. 1b). Each nest consisted of three lysimeters and thus produced an equal number of monthly replicates per sampling location. The lysimeter distribution along the V-shaped Shale Hills Critical Zone Observatory (Pennsylvania, USA; see Brantley et al., 2018, for a review) inspired our sampling design at UDL. The lysimeters in each nest were separated 6 to $10 \mathrm{~m}$ apart. The lysimeters were pressurized at the beginning of each sampling period using an electrical vacuum pump to 750 bar below the atmospheric pressure at the time of sampling. During the first 12 months, soil solutions were collected each month and dis- carded. Following equilibration, the soil solutions were collected in $2 \mathrm{~L}$ PE bottles placed in a shallow soil pit. Monthly hydrochemical sampling of the lysimeters was performed during the following 2 hydrological years, i.e., from November 2011 to October 2013. The collected soil solutions included both capillary and water percolating the mineral soil (e.g., Nieminen et al., 2016).

\subsection{Soil samples}

Five $0.5 \mathrm{~m}^{2}$ soil pits were excavated in July 2015 at some distance from the previously installed suction lysimeter nests to avoid disturbances to the zero tension soil solution collection systems (Fig. 1b) while preserving a soil profile equivalent to the one at the nearby nest and also the relative position within the catchment area. The pits were excavated and processed by using the methodology described by Huntington et al. (1988) along both slopes of the UDL catchment (open circles in Fig. 1b). Forest floor and mineral soil were removed to a depth of $\sim 80 \mathrm{~cm}$ below the surface and separated into topsoil in which plants have their roots, and which is comprised of the $\mathrm{Oi} /(\mathrm{L})+\mathrm{Oe}(\mathrm{F})$ and $\mathrm{Oa}(\mathrm{H})$ as well as the top soil layers defined by depth $(0-10,10-20 \mathrm{~cm})$ (not investigated here); and subsoil comprised by the $20-40$ and $40-80 \mathrm{~cm}$ mineral soil layers. The soil layers were weighed in the field, processed by sieving to separate the stones; coarse roots, and the $>1 \mathrm{~cm}$ soil fraction. Two kilograms of the $<1 \mathrm{~cm}$ soil fraction were transported to the laboratory. Only results from the $40-80 \mathrm{~cm}$ soil level are reported in this work. This level is considered to be in chemical equilibrium with waters collected by our $50 \mathrm{~cm}$ depth lysimeter nests and corresponds to horizon Bs2 in all plots. 

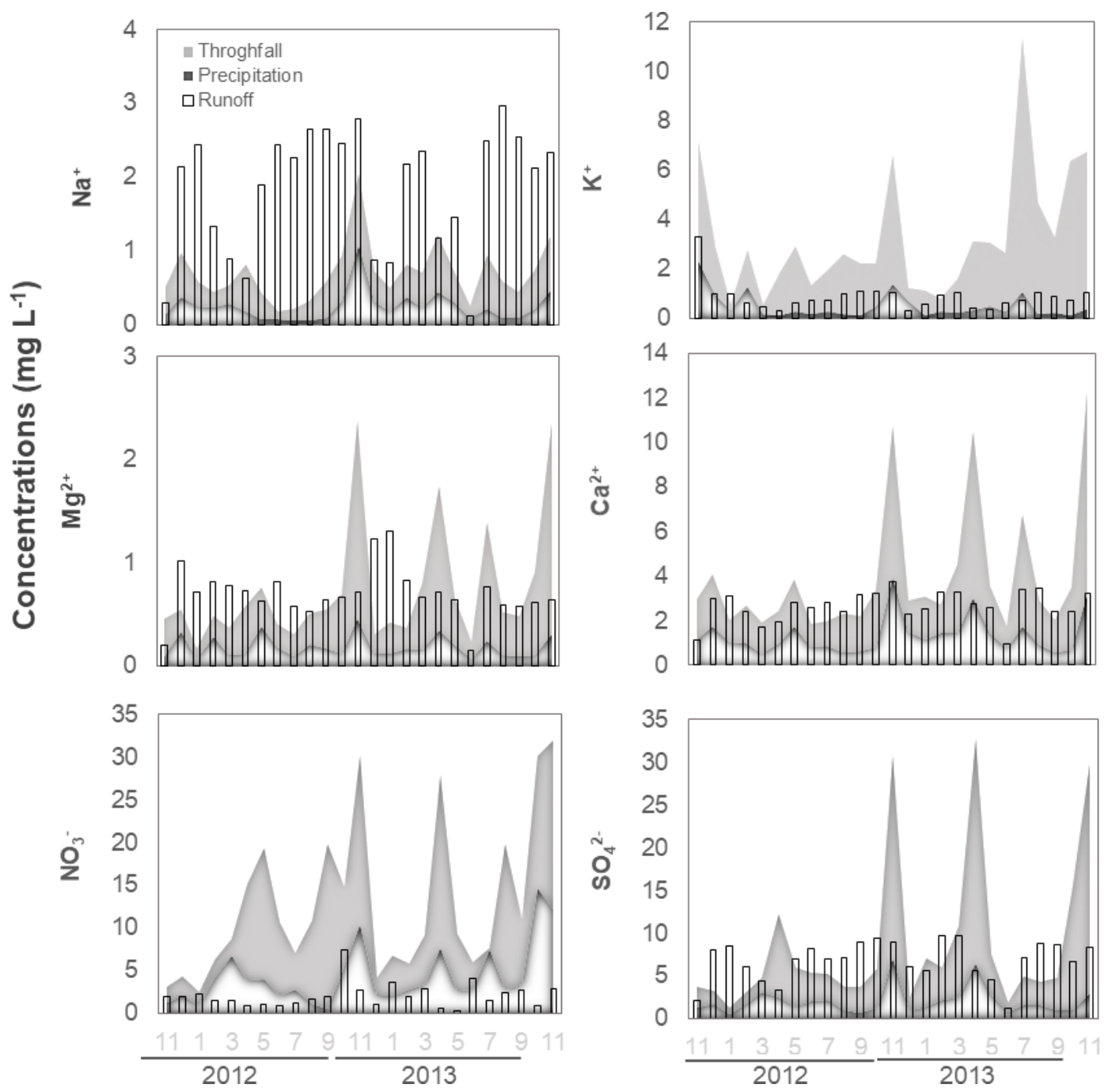

Figure 2. Hydrochemical data relevant for the monitoring period (2012-2013). The $x$ axis shows months and hydrological year; concentrations following Oulehle et al. (2017).

\subsection{Bulk atmospheric deposition and stream water samples}

Atmospheric deposition was sampled in open areas ("rainfall"), with sampling sites being $20 \mathrm{~m}$ apart among them and $1.2 \mathrm{~m}$ above ground (open square in Fig. 1b). Cumulative rainfall was collected monthly in three replicates. For oxygen isotope analyses, diffusive and evaporative losses from narrow-mouth bulk rain collectors were avoided by keeping precipitation under a $5 \mathrm{~mm}$ layer of chemically stable mineral oil. Stream water samples and runoff flux estimations were collected monthly at a V-notch weir in the limnigraph location (Fig. 1b) according to methods outlined in Kram et al. (2003).

\subsection{Analyses}

\subsubsection{Soil characterization}

A Radiometer TTT-85 pH meter with a combination electrode was used to measure $\mathrm{pH}_{\mathrm{H}_{2} \mathrm{O}}$ of soil (soil-water suspension ratio $=1: 2.5$ ). Soil texture was analyzed by the hydrometer method (ISO 11277 2009). Following air drying, the mineral substrate was sieved through a $2 \mathrm{~mm}$ sieve. The sieved samples were kept at $5^{\circ} \mathrm{C}$ before chemical analysis. Exchangeable cations in soils were analyzed in $0.1 \mathrm{M} \mathrm{BaCl}_{2}$ extracts by atomic absorption spectrophotometry (AAS, AAnalyst Perkin Elmer 200). Exchangeable acidity was determined by titration of the extracts. Cation exchange capacity (CEC) was calculated as the sum of exchangeable base cations and exchangeable acidity. Base saturation (BS) was determined as the fraction of CEC associated with base cations. The concentrations of $\mathrm{NO}_{3}^{-}$and $\mathrm{SO}_{4}^{2-}$ from the soil 
extracts described above were determined by ion chromatography (HPLC Knauer 1000), with a limit of quantification (D.L.) of 0.1 and $0.3 \mathrm{mg} \mathrm{L}^{-1}$, respectively. For an estimation of phosphorus $(\mathrm{P})$ release, ammonium oxalate extractions were performed by following the protocol described in Schoumans (2000). In short, a reagent solution consisting of $\left(\mathrm{COONH}_{4}\right)_{2} \cdot \mathrm{H}_{2} \mathrm{O}$ and $(\mathrm{COOH})_{2} \cdot 2 \mathrm{H}_{2} \mathrm{O}$ was used to dissolve $1 \mathrm{~g}$ of the $<2 \mathrm{~mm}$ soil fraction. Extractable phosphorus $\left(\mathrm{P}_{\mathrm{ox}}\right)$, iron $\left(\mathrm{Fe}_{\mathrm{ox}}\right)$, and aluminum $\left(\mathrm{Al}_{\mathrm{ox}}\right)$ were determined by shaking duplicate samples of soils with $30 \mathrm{~mL}$ of $0.5 \mathrm{M}$ acidified (pH 3.0) reagent in $50 \mathrm{~mL}$ centrifuge tubes for $2 \mathrm{~h}$ in the dark. After shaking, centrifugation and filtration, the soil solutions were examined through inductively coupled plasma-atomic emission spectroscopy. The $\mathrm{P}_{\mathrm{ox}}, \mathrm{Fe}_{\mathrm{ox}}$, and $\mathrm{Al}_{\mathrm{ox}}$ concentrations were used to estimate the degree of $\mathrm{P}$ saturation of the soil [DPS $\mathrm{Dx}_{\mathrm{ox}}=\mathrm{P}_{\mathrm{ox}} *\left(0.5 *\left(\mathrm{Fe}_{\mathrm{ox}}+\mathrm{Al}_{\mathrm{ox}}\right)^{-1}\right)$ ], which accounts for the $\mathrm{P}$ available to be released into solution in relation to the remaining binding capacity of the soil and, thus, allows identification of areas in the catchment with relatively higher potential for P export (Beauchemin and Simard, 1999; Borovec and Jan, 2018). For calculations of the amount of $P$ sorbed by soil particles (Borovec and Jan, 2018), the average stream water $\mathrm{P}$ concentration, measured during our 2-year monitoring period (i.e., $27.9 \pm 6.5 \mu \mathrm{g} \mathrm{L}^{-1}$ ), was used as an input for calculating the equilibrium $\mathrm{P}$ concentration in the catchment area.

\subsubsection{Soil solutions}

Concentrations of $\mathrm{NH}_{4}^{+}$and total phosphorus $\left(\mathrm{P}_{\text {tot }}\right)$ were measured spectrophotometrically (Perkin-Elmer Lambda 25; $>20$ and $6 \mu \mathrm{g} \mathrm{L}^{-1}$, respectively). Concentrations of $\mathrm{Na}^{+}, \mathrm{K}^{+}$, $\mathrm{Ca}^{2+}$ and $\mathrm{Mg}^{2+}$ were determined by electrothermal atomic absorption spectrometry (AAnalyst $200 ;>5 \mu \mathrm{g} \mathrm{L}^{-1}$ ). Concentrations of aluminum $\left(\mathrm{Al}^{3+}\right)$ were measured by electrothermal atomic absorption with a graphite furnace (D.L. $<0.01 \mathrm{mg} \mathrm{L}^{-1}$ ). Concentrations of DOC and total dissolved nitrogen (TN) were determined on a combustion analyzer (Torch, Teledyne Temar; D.L. $<0.1$ and $0.5 \mathrm{mg} \mathrm{L}^{-1}$ ).

\subsubsection{Statistical analysis}

The non-normally distributed (i.e., non-parametric) data was evaluated by factor analysis. Empirical data were implemented in the computer code XLSTAT following the protocol by Vega et al. (1998). In short, data were normalized to zero and unit variance, and a covariance matrix of the normalized species was generated. For this analysis, the covariance matrix was diagonalized and the characteristic roots (eigenvalues) were obtained. The transformed variables, or principal components (PCs) so obtained were weighted linear combinations of the original plotted multidimensional variables. A rotation of PCs allowed a simpler and more meaningful representation of the underlying factors by decreasing the contribution of each variables to the two-dimensional plane.
The variables can then be plotted in groups with correlation among them being determined by their position (e.g., proximity, distance, orthogonality). The two-dimensional plane where the rotated, normalized data were plotted can be interpreted in terms of the main controls over the general variance of the dataset (see Vega et al., 1998, for details).

\section{Results}

Table 2 lists physical data for mineral soil and chemical data for soil extracts from the $40-80 \mathrm{~cm}$ depth layer and data for soil solutions collected by suction lysimeters $(50 \mathrm{~cm}$ depth). As described above, the dataset is grouped according to sampling position within the catchment area (i.e., hilltops, slopes, and valley; Fig. 1).

\subsection{Soil textural characterization}

In the eastern part of the catchment, coarse soil particles (gravel and stones) accounted for $24 \%$ on the hillslope and $62 \%$ of total soil granulometry at the hilltop, whereas in the western part of the catchment the soil particles above $10 \mathrm{~cm}$ in size accounted only for $\sim 12 \%$ (Table 2 ). The soil texture is loamy sand, with the presence of authigenic clays (7\%$15 \%)$ as weathering-induced alteration products of the orthogneiss parental material. The groundwater table is shallow.

\subsection{Soil chemical characterization}

\subsection{1 $\mathrm{pH}, \mathrm{CEC}$, and $\mathrm{BS}$}

The soil at the $40-80 \mathrm{~cm}$ depth layer was characterized by $\mathrm{pH}_{\mathrm{H}_{2} \mathrm{O}}<5$ (Table 2). This median mineral soil layer had higher $\mathrm{pH}$ in the valley (4.7) compared to the hilltop (4.4 to 4.2 units). The mean $\mathrm{pH}$ of soil solutions ranged similarly between the first and the second year, except for in the valley ( $\mathrm{pH}=4.1$ to 4.8 ; Table 2). The 2-year averages of soil solutions were 5.2, 4.7, and $4.3 \mathrm{pH}$ units on the hilltops, slopes, and valley, respectively. Therefore, the solid substrate extracts and soil solutions were characterized by an opposite elevational $\mathrm{pH}$ trend; i.e., more acidic soil extracts uphill, more acidic soil solution downhill.

In the eastern part of the catchment, the average cation exchange capacity (CEC) of the mineral soil at $40-80 \mathrm{~cm}$ depth was up to 33 meq kg $\mathrm{on}^{-1}$ the slope and $58 \mathrm{meq} \mathrm{kg}-1$ on the hilltop (Table 2). By contrast, in the western part, the CEC was 22 and 19 meq $\mathrm{kg}^{-1}$, which is lower than the mean CEC values measured at all of the plots at UDL, whilst CEC in the valley was $27 \mathrm{meq} \mathrm{kg}^{-1}$, which is within the mean CEC values measured at all of the plots at UDL: $32 \pm 7$ meq kg-1 (Table 2). The range of BS values in the soil varied between $6 \%$ and $13 \%$, with higher BS observed in the east $(>9 \%)$ as compared to the west $(<8 \%)$. The CEC in the studied soil depth at UDL was dominated by exchangeable 
Table 2. Spatially resolved physical and geochemical data for solid substrate (40-80 cm depth) and annual average soil solution chemistries at the $50 \mathrm{~cm}$ depth.

\begin{tabular}{|c|c|c|c|c|c|c|c|c|c|c|}
\hline Measurement & \multicolumn{2}{|c|}{ Hilltop W } & \multicolumn{2}{|c|}{ Slope W } & \multicolumn{2}{|c|}{ Valley } & \multicolumn{2}{|c|}{ Slope E } & \multicolumn{2}{|c|}{ Hilltop E } \\
\hline $\mathrm{CEC}\left(\mathrm{meq} \mathrm{kg}^{-1}\right)$ & & 19.4 & & 22.6 & & 27.2 & & 33.4 & & 58.4 \\
\hline $\mathrm{BS}(\%)$ & & 7.5 & & 6.4 & & 7.7 & & 9.2 & & 12.5 \\
\hline$>10 \mathrm{~cm}\left(\mathrm{~kg} \mathrm{ha}^{-1}\right) \times 10^{3 \mathrm{a}}$ & & 0 & & 75 & & 0 & & 141 & & 2038 \\
\hline$<2 \mathrm{~mm}\left(\mathrm{~kg} \mathrm{ha}^{-1}\right) \times 10^{3 \mathrm{a}}$ & & 4707 & & 2842 & & 2199 & & 3726 & & 1102 \\
\hline $\mathrm{pH}_{\mathrm{H}_{2} \mathrm{O}}$ & & 4.2 & & 4.6 & & 4.7 & & 4.7 & & 4.4 \\
\hline $\mathrm{Na}^{+}\left(\mathrm{mg} \mathrm{kg}^{-1}\right)$ & & 3 & & 6 & & 17 & & 6 & & 34 \\
\hline $\mathrm{K}^{+}\left(\mathrm{mg} \mathrm{kg}^{-1}\right)$ & & 30 & & 19 & & 4 & & 29 & & 7 \\
\hline $\mathrm{Mg}^{2+}\left(\mathrm{mg} \mathrm{kg}^{-1}\right)$ & & 2 & & 8 & & 4 & & 9 & & 27 \\
\hline $\mathrm{Ca}^{2+}\left(\mathrm{mg} \mathrm{kg}^{-1}\right)$ & & 7 & & 27 & & 20 & & 26 & & 78 \\
\hline $\mathrm{C}_{\text {org }}(\%)$ & & 0.40 & & 0.81 & & 0.99 & & 0.45 & & 1.81 \\
\hline $\mathrm{TN}(\%)$ & & 0.020 & & 0.037 & & 0.045 & & 0.032 & & 0.101 \\
\hline $\mathrm{Al}_{\mathrm{Ox}}\left(\mathrm{mg} \mathrm{kg}^{-1}\right)$ & & 3880 & & 5490 & & 4390 & & 2550 & & 2370 \\
\hline $\mathrm{Fe}_{\mathrm{Ox}}\left(\mathrm{mg} \mathrm{kg}^{-1}\right)$ & & 1040 & & 2500 & & 3950 & & 2810 & & 4150 \\
\hline $\mathrm{P}_{\mathrm{Ox}}\left(\mathrm{mg} \mathrm{kg}^{-1}\right)$ & & 352 & & 421 & & 334 & & 450 & & 536 \\
\hline $\mathrm{DPS}_{\mathrm{ox}}^{\mathrm{b}}$ & & 0.14 & & 0.10 & & 0.08 & & 0.17 & & 0.16 \\
\hline Measurement & 2012 & 2013 & 2012 & 2013 & 2012 & 2013 & 2012 & 2013 & 2012 & 2013 \\
\hline \multicolumn{11}{|l|}{ Soil solution ${ }^{\mathrm{c}}$} \\
\hline pH & 5.4 & 5.5 & 4.6 & 4.4 & 4.1 & 4.5 & 5.0 & 4.8 & 4.9 & 4.9 \\
\hline $\mathrm{SO}_{4}^{2-}$ & 3132 & 3270 & 4850 & 4770 & 4420 & 5000 & 5440 & 5640 & 3360 & 3400 \\
\hline $\mathrm{NO}^{3-}$ & 63 & 58 & 1800 & 1300 & 9870 & 4040 & 155 & 181 & 149 & 117 \\
\hline $\mathrm{NH}_{4}^{+}$ & $<20$ & $<20$ & $<20$ & $<20$ & $<20$ & 30 & $<20$ & $<20$ & $<20$ & 70 \\
\hline DOC & 13500 & NM & 8440 & NM & 4510 & NM & 4230 & NM & 15100 & NM \\
\hline $\mathrm{Al}^{3+}$ & 1130 & 1170 & 945 & 859 & 1590 & 1280 & 396 & 394 & 1130 & 1150 \\
\hline $\mathrm{Na}^{+}$ & 455 & 493 & 611 & 662 & 683 & 687 & 1050 & 1040 & 618 & 649 \\
\hline $\mathrm{K}^{+}$ & 184 & 161 & 177 & 145 & 340 & 225 & 430 & 378 & 179 & 128 \\
\hline $\mathrm{Mg}^{2+}$ & 897 & 1000 & 700 & 699 & 445 & 378 & 505 & 539 & 775 & 764 \\
\hline $\mathrm{Ca}^{2+}$ & 699 & 806 & 498 & 531 & 459 & 514 & 794 & 851 & 668 & 697 \\
\hline
\end{tabular}

${ }^{a}$ Soil particulate size. ${ }^{b}$ Degree of $\mathrm{P}$ saturation $\left(\mathrm{DPS}=\mathrm{P}_{\mathrm{OX}} \cdot\left(0.5 \cdot\left(\mathrm{Fe}_{\mathrm{ox}}+\mathrm{Al}_{\mathrm{ox}}\right)^{-1}\right)\right) \cdot{ }^{\mathrm{c}}$ Concentrations in $\mu \mathrm{g} \mathrm{L}{ }^{-1}$. NM: not measured; variation coefficients are given in the Supplement.

Al. Consequently, the soil $\mathrm{BS}$ and soil $\mathrm{pH}_{\mathrm{H}_{2} \mathrm{O}}$ values were also low (Table 2). In summary, cation exchange capacity in UDL soils developed on base-poor orthogneiss ranged between 19 and $58 \mathrm{meq} \mathrm{kg}^{-1}$ and base saturation was from $6 \%$ to $13 \%$. Both parameters had lower values than median values at the European LTER sites $\left(84 \mathrm{meq} \mathrm{kg}^{-1}\right.$ and $30 \%$, respectively). With regard to other analogous central European forest ecosystems, soil solution solute concentrations in UDL were found above values also reported throughout the evaluation of temporal changes in inputs, runoff and fluxes (e.g., Manderscheid and Matzner, 1995; Manderscheid et al., 1995; Wesselink et al., 1995, Hruska et al., 2001; Armbruster and Feger, 2004; Oulehle et al., 2006; Navratil et al., 2007).

BS at UDL was classified as poor with the dominant equivalent proportion of divalent base cations $\mathrm{Ca}^{2+}$ (mean $46 \%$ ) and $\mathrm{Mg}^{2+}$ (mean 24\%). The BS at UDL is twofold higher than the BS determined at similar soil depths in the leucogranitic catchment LYS (Kram et al., 1997; Hruska et al., 2001), which is the most acidified catchment of the Czech monitoring network (Oulehle et al., 2017). Holmberg et al. (2018) evaluated BS and CEC of numerous forest sites of the LTER (Long-Term Ecological Research) network in nine European countries, with calculated median BS of $30 \%$ and CEC of $84 \mathrm{meq} \mathrm{kg}^{-1}$. From the European perspective, the soil BS and CEC values at the UDL were low.

\subsubsection{Solute concentrations}

Mean concentrations of individual chemical species, such as DOC, sulfate, nitrate, base cations, aluminum, chloride, and $\mathrm{pH}$ values in soil solutions collected at the $50 \mathrm{~cm}$ depth are listed separately for the years 2012 and 2013 (Table 1), whilst Fig. S1 in the Supplement shows the spatial variability of the statistical distribution (minimum, first quartile, median, third 
quartile and maximum; (in $\mathrm{mg} \mathrm{L}^{-1}$ ). Coefficients of variation within individual nests of lysimeters are listed in Table S1.

Concentrations of organic C (DOC) ranged between 0.40 and $1.81 \mathrm{wt} \%$, while concentrations of total nitrogen (TN) were between 0.02 and $0.10 \mathrm{wt} \%$, with [TN] being highest on hilltop east, and lowest on hilltop west (Table 2). Oxalateextractable $\mathrm{P}$ was the lowest in the valley $\left(334 \mathrm{mg} \mathrm{kg}^{-1}\right)$, and highest on hilltop east $\left(536 \mathrm{mg} \mathrm{kg}^{-1}\right)$. The degree of P saturation varied between 0.08 (valley) and 0.16 (hilltop east). These values fall below the lowest range observed in soil plots from the Czech Republic (see Borovec and Jan, 2018), pointing to a potential $\mathrm{P}$ deficit in the ecosystem.

Sulfate concentrations in soil solutions were on average $37 \%$ lower than those in stream water, while relative to stream waters, $\mathrm{NO}_{3}^{-}$concentrations in soil solutions were $14 \%$ lower. Similarly, the concentrations of $\mathrm{K}^{+}, \mathrm{Na}^{+}, \mathrm{Ca}^{2+}$ and $\mathrm{Mg}^{2+}$ were lower in soil solutions by $73 \%, 63 \%, 79 \%$ and $4 \%$, respectively. The combined dataset (Tables 1 and 2) shows that except for DOC and $\mathrm{Al}^{3+}$, the rest of the studied chemical species were more diluted in the $50 \mathrm{~cm}$ soil solutions than in the stream waters.

A time-series plot reveals that $\mathrm{SO}_{4}^{2-}$ concentrations in the valley were higher in winter than in summer (Fig. 3). The mean $\mathrm{SO}_{4}^{2-}$ concentrations in soil solution during the monitored period were found to be highest on the slopes (east $>$ west), followed by the valley and hilltops (east $\approx$ west) (Table 2, Fig. S1 in the Supplement). Our results for $\mathrm{NO}_{3}^{-}$across the lysimeter network also show that this chemical species was readily bioavailable along the study site but mostly in the valley, where its concentrations were one order of magnitude higher than in the upslope soil solutions (Fig. S1). For this anion, the dataset also shows a high temporal variability, and in both years, $\mathrm{NO}_{3}^{-}$concentrations peaked by late spring in the valley (Fig. 3). By comparison, the belowground $\mathrm{NH}_{4}^{+}$concentrations were found to be low (usually below the limit of quantification, Table 2), a result that is consistent with previous observations from a soil research plot in the north-western Czech Republic (Oulehle et al., 2006). For $\mathrm{SO}_{4}^{2-}$ and $\mathrm{NO}_{3}^{-}$, coefficients of variation were between $2 \%$ and $17 \%$, with no clear-cut differences within the sampling locations (Table S1).

Mean $\mathrm{Na}^{+}$and $\mathrm{K}^{+}$concentrations in soil solutions were the highest on slope east (Table 2; Fig. S1). For these cations, coefficients of variation (Table S1) were between $9 \%$ and $55 \%$, with the hilltop soil solutions exhibiting the largest variation in $\mathrm{K}^{+}$concentrations. The second year was characterized by generally lower $\mathrm{K}^{+}$concentrations in soil solutions collected in the valley, compared to the first year. $\mathrm{Na}^{+}$ concentrations in soil solutions in the valley started to decrease only in the second half of the second year (Fig. 3).

As shown in Table 2, the highest mean $\mathrm{Mg}^{2+}$ concentrations were observed on hilltop west, while the highest mean $\mathrm{Ca}^{2+}$ concentrations were measured on slope east. The lowest mean $\mathrm{Mg}^{2+}$ and $\mathrm{Ca}^{2+}$ concentrations were found in the valley (Table 2, Fig. S1). Coefficients of variations for $\mathrm{Mg}^{2+}$ and $\mathrm{Ca}^{2+}$ in soil solutions were relatively low, between $6 \%$ and $21 \%$ (Table S1). The time series of $\mathrm{Ca}^{2+}$ concentrations exhibited localized maxima in spring/early summer of the second year in soil solutions collected in most locations. Except for slope east, other locations also exhibited indistinct maxima in $\mathrm{Mg}^{2+}$ concentrations in soil solutions in the spring to early summer of the second monitored year (Fig. 3).

\subsection{Statistical analysis}

Several spatial trends are evident by evaluating the statistical distribution of anions and cations in the soil solutions (Table 2; Fig. S1). Throughout the monitored period there was a weak correlation between atmospheric deposition, stream water and soil solution concentrations (Fig. S2). The first factor of our explorative factor analysis, D1, exhibited a maximal overall variance that explained $24 \%$ of total intercorrelated variance of collected data. The second factor, D2, had maximal variance amongst all unit length linear combinations that were uncorrelated with D1 and explained $18 \%$ of variance within the dataset (Fig. S1). Based on the weights of the parameters, correspondence to each of these factors, and their cluster distribution, intrinsic properties of the soil, such as its DOC and clay contents (i.e., D1), determined the variance on the soil solution solute concentration to a higher degree than seasonal inputs (i.e., D2).

\section{Discussion}

\subsection{Comparison with other European forests}

A comparison of previous studies with data presented here is not straightforward due to differences in sampling and analytical strategies, dissimilar and heterogeneous bedrock lithologies, variable soil buffering capacities, and other factors such as canopy density, inter-annual water influx variability and tree species diversity. Nonetheless, insights from previous related studies provide the framework for our interpretations. Johnson et al. (2018) have recently published soil solution data from 162 plots monitored as part of the (ICP) Forest monitoring network, including median concentrations of environmentally relevant chemical species for the years 1998-2012. Soil solutions in the 40-80 cm deep mineral subsoil across Europe typically contained $6.3 \mathrm{mg} \mathrm{SO}_{4}^{2-} \mathrm{L}^{-1}, 1.0 \mathrm{mg} \mathrm{NO}_{3}^{-} \mathrm{L}^{-1}, 1.9 \mathrm{mg} \mathrm{Ca}^{2+} \mathrm{L}^{-1}$, and $0.7 \mathrm{mg} \mathrm{Mg}^{2+} \mathrm{L}^{-1}$ (i.e., median values). Considering those values alone, it follows that soil solutions at UDL in 20122013 were characterized by analogue concentrations of $\mathrm{SO}_{4}^{2-}, \mathrm{Ca}^{2+}$ and $\mathrm{Mg}^{2+}$ as the ICP sites, and about one order of magnitude higher $\mathrm{NO}_{3}^{-}$concentrations than the ICP sites. Increased nitrate leaching toward the mineral soil in the UDL' forest ecosystems clearly reflects its $\mathrm{N}$-saturated state (Aber et al., 1989; MacDonald et al., 2002). 

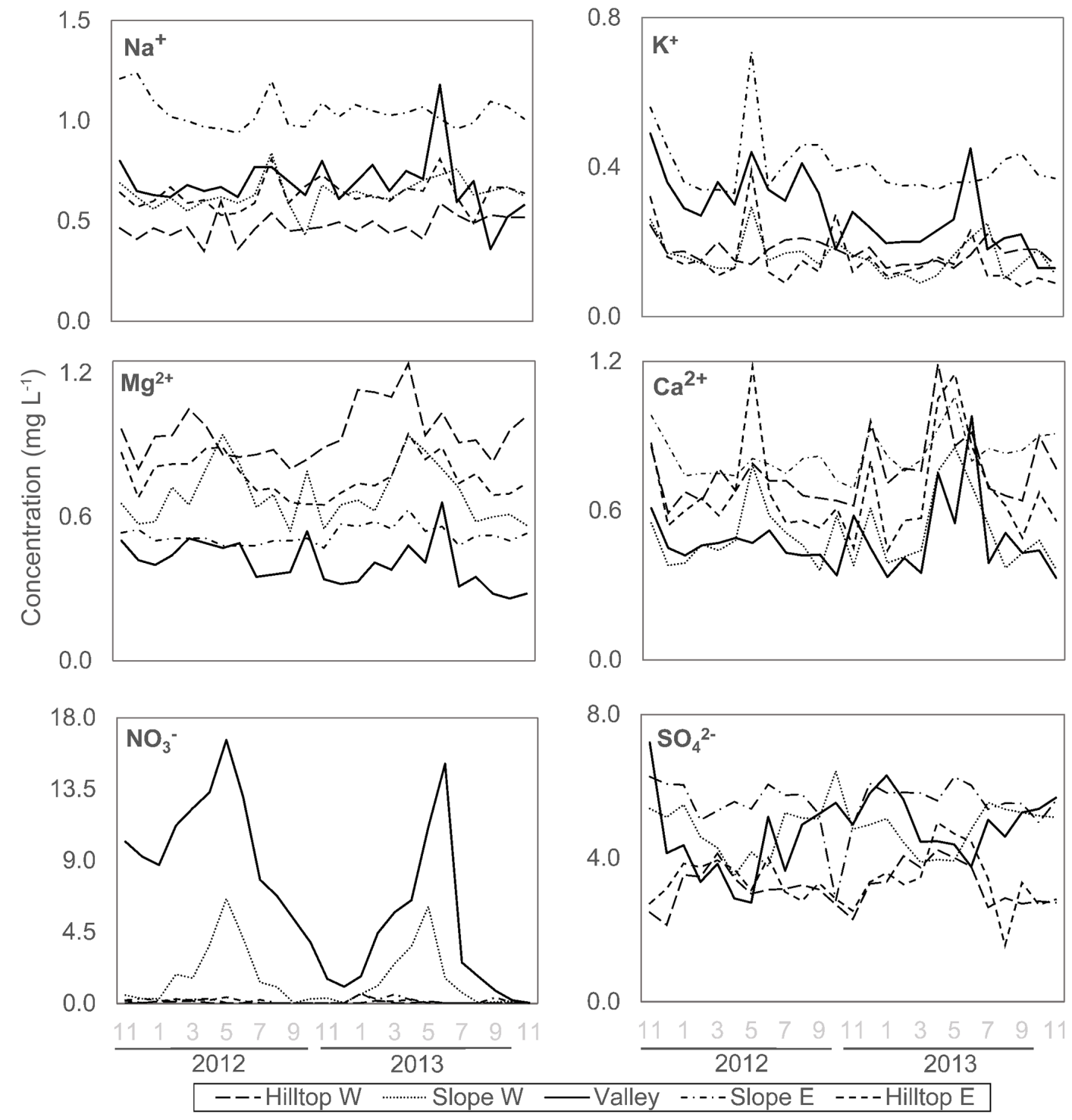

Figure 3. Spatially resolved, time-series soil solution concentration values of base cations, sulfate and nitrate at $50 \mathrm{~cm}$ depth. The $x$ axis shows months and hydrological year.

\subsection{Recovery from acidification as observed in the spatial and temporal variability of soil solution chemistries}

In all studied soil solutions, a decreasing trend downhill was found in $\mathrm{pH}$, DOC and $\mathrm{Ca}^{2+}$ and $\mathrm{Mg}^{2+}$ concentrations (Table 2; Figs. 3 and S1). Amongst such trends, those of $\mathrm{pH}$ exhibiting a downhill 0.6 units difference, and DOC with concentrations lower by a factor of 2 to 3 in the valley as compared with hilltops, contrast with a rather moderate downslope decrease in soil solution $\mathrm{Ca}^{2+}$ and $\mathrm{Mg}^{2+}$ concentration trends, of which differences within the catchment area do not exceed $1 \mathrm{mg} \mathrm{L}^{-1}$. Our time series data shows that $\mathrm{Ca}^{2+}$ and $\mathrm{Mg}^{2+}$ in soil solutions defined a general trend likely reflective of the balance between evapotranspiration and biological inputs, with a punctual and correlative shift recorded in concentrations measured during mid-2013 (Table 2). This punctual correlative increase in these ions can be linked to an increase in strong anions inputs (Fig. 2), yet increased leaching of these macronutrients could also be regulated by temporary changes in the soil nitrate abundance (Oulehle et al., 2006; Wesselink et al., 1995; Akselsson et al., 2007, 2008). For DOC, the high variability on the slopes may reflect preferential flow paths. A relatively higher DOC belowground leaching on the eastern hilltop can be inferred from the data, which suggests that $C$ partitioning is site-specific, with little lateral redistribution from upslope organic soil levels toward the valley. Higher than topsoil mobilization of DOC below the rooted soil levels can be considered as a proxy for 
an incomplete recovery from acidification (Verstraeten et al., 2017).

Clear-cut seasonal concentration trends in soil solutions were recorded for $\mathrm{NO}_{3}^{-}$and $\mathrm{SO}_{4}^{2-}$ (valley and slope west; Table 2). The underlying mechanism may be different for both anions. The co-evaluation of peak nitrate levels in soil solutions and precipitation inputs during the monitoring period (Fig. S3) does not suggests a cause-effect relation linked to atmospheric deposition. Thus, higher abundance of $\mathrm{NO}_{3}^{-}$ in soil solutions in the growing season may be related to higher rates of nitrification of organically cycled $\mathrm{NH}_{4}^{+}-\mathrm{N}$ during summer (e.g., van Miegroet and Cole, 1984). Higher abundance of $\mathrm{SO}_{4}^{2-}$ in soil solutions in winter remains unexplained. Historically, more soil $\mathrm{S}$ pollution was caused by higher $\mathrm{SO}_{x}$ emissions from nearby coal-burning power plants during the cold season, but such seasonality was no longer seen for the years 2012-2013 (Fig. 2). Hence, it is thought that nitrate in soil solutions during summer originated during the dormant season, whilst high sulfate concentrations observed during winter times originate from organic $\mathrm{S}$ being recycled and accumulated during the summer (Mayer et al., 2001; Novak et al., 2001). As shown by Novak et al. (2005) using sulfur isotope ratios $\left({ }^{34} \mathrm{~S}:{ }^{32} \mathrm{~S}\right)$, cycling of the high amounts of deposited $\mathrm{SO}_{x}$ at UDL occurred not only by adsorption/desorption of $\mathrm{SO}_{4}^{2-}$ onto soil particles, but also, to a great extent, by cycling through the soil organic matter. As a consequence, acidification and export of $\mathrm{SO}_{4}^{2}$, and for that matter, legacy reactive $\mathrm{N}$, may prevail for several decades in the UDL as well as other similarly polluted mountain catchments (Novak et al., 2000; Armbruster et al., 2003; Mörth et al., 2005). Similarly, in UDL decreased runoff $\mathrm{NO}_{3}^{-}$ export seems to be rather controlled by biological processes than by catchment hydrology (Oulehle et al., 2017). This is in association with increased organic productivity, due to excess $\mathrm{N}$, and because of the managed restoration of hardwood species following spruce die-back in UDL. Along with an increased total (aboveground) biomass immobilization of a large proportion of the atmospherically deposited $\mathrm{NO}_{3}^{-}$and $\mathrm{NH}_{4}^{+}$(e.g., McDowell et al., 2004), there was a concomitant increase in the demand for $\mathrm{P}$, thus leading to an ecosystem deficiency on this macronutrient in the soil compartment.

Due to pollution abatement policies, atmospheric input has decreased since peak acidification, yet UDL has been previously characterized by higher export of $\mathrm{SO}_{4}^{2-}$, DOC, $\mathrm{Ca}^{2+}$, $\mathrm{Mg}^{2+}, \mathrm{K}^{+}$, and $\mathrm{Na}^{+}$than their atmospheric input. In this regard, biogeochemical process within the soil seem to release more non-conservative ions than received from the atmosphere. Interestingly, export of total inorganic N from UDL via stream runoff continues to be significantly lower than its atmospheric input, but our results show that $\mathrm{N}$ leaching toward the subsoil levels is higher than runoff. Differences in porosity and greater fluid-rock-derived particle interactions, together with higher reactive surface areas and solute fluxes, might also exert a control over the measured soil solution chemical variability (Godsey et al., 2009). The latter effect seems to be a critical control over the variability in soil solution chemistries at the hilltops, where the subsoil level contains significant amounts of coarse parental-rock material (Table 2).

For $\mathrm{Na}^{+}$and $\mathrm{K}^{+}$ions in soil solutions, our spatially resolved time-series observations (Fig. 3) show that their concentrations defined patterns and trends largely derived from heterogeneity in soil granulometry (Table 2), with seasonality and pulses in atmospheric inputs also exerting some control over their concentrations is soil solutions (cf. Figs. 2 and 3). For $\mathrm{K}^{+}$, and to a minor extent for $\mathrm{Na}^{+}$, soil solution concentrations recorded peaks that are more or less correlative with $\mathrm{SO}_{4}^{2-}$ and $\mathrm{NO}_{3}^{-}$inputs (cf. Figs. 2 and 3), again pointing to lapses in which the atmospheric contribution of strong anions exerted a significant control over the weathering and leaching of plagioclase and K-feldspar minerals in the bedrock (e.g., Moore et al., 2012). Oulehle et al. (2017) reported that $\mathrm{K}^{+}$average annual runoff was 2 to 3 times higher than that of $\mathrm{Na}^{+}$(Table 1), with both cations exceeding runoff concentrations values measured in other monitored catchments. When the spatial variations in $\mathrm{Na}^{+}$and $\mathrm{K}^{+}$at the $50 \mathrm{~cm}$ depth soil solutions are also evaluated, a deep flow path within the eastern slope to the valley seems possibly augmented as a response of the solubilization of the $\mathrm{SO}_{4}^{2-}$ atmospherically deposited and/or stored in the weathering zone below the rooted soils due to soil water saturation. Because $\mathrm{Na}^{+}$has low affinity toward organic and inorganic ligands in soil, and, thus, behaves relatively conservatively (McIntosh et al., 2017), a seemingly more rapid response of $\mathrm{Na}^{+}$than $\mathrm{K}^{+}$leaching to soil solutions could be interpreted as the result of the episodic accumulation of strong anions belowground (cf. Figs. 2 and 3; e.g., Spring 2013). From this result, it can be argued that localized and punctual chemical analyses of runoff waters in mountain catchments might not directly reflect nutrient partitioning trends along elevation gradients, but temporal variations of the strong anion content of the water table, which has implications for the design of studies centred in stream water analyses for depicting the coupling of soil development processes and hydrology over variable timescales and between deep and shallow weathering processes.

The behaviour of $\mathrm{Na}^{+}$vs. $\mathrm{K}^{+}$ions can also be interpreted as a decrease in water residence time from the slope to the valley. On this note, we followed the modelling approach implemented by Buzek et al. $(1995,2009)$ to provide further insight into the mean residence time of soil solutions calculated across all sampling locations which was estimated in approximately 8.3 months (Appendix A). In consequence, the runoff water at UDL is a mixture of direct precipitation with older soil solutions admixed with even older shallow groundwater. The supplementary isotopic modelling implemented here also shows that direct precipitation contributes between $20 \%$ and $40 \%$ of the discharge, with the rest being local soil pore waters and groundwaters (Appendix A). The combination of all these three water types is called "mobile 

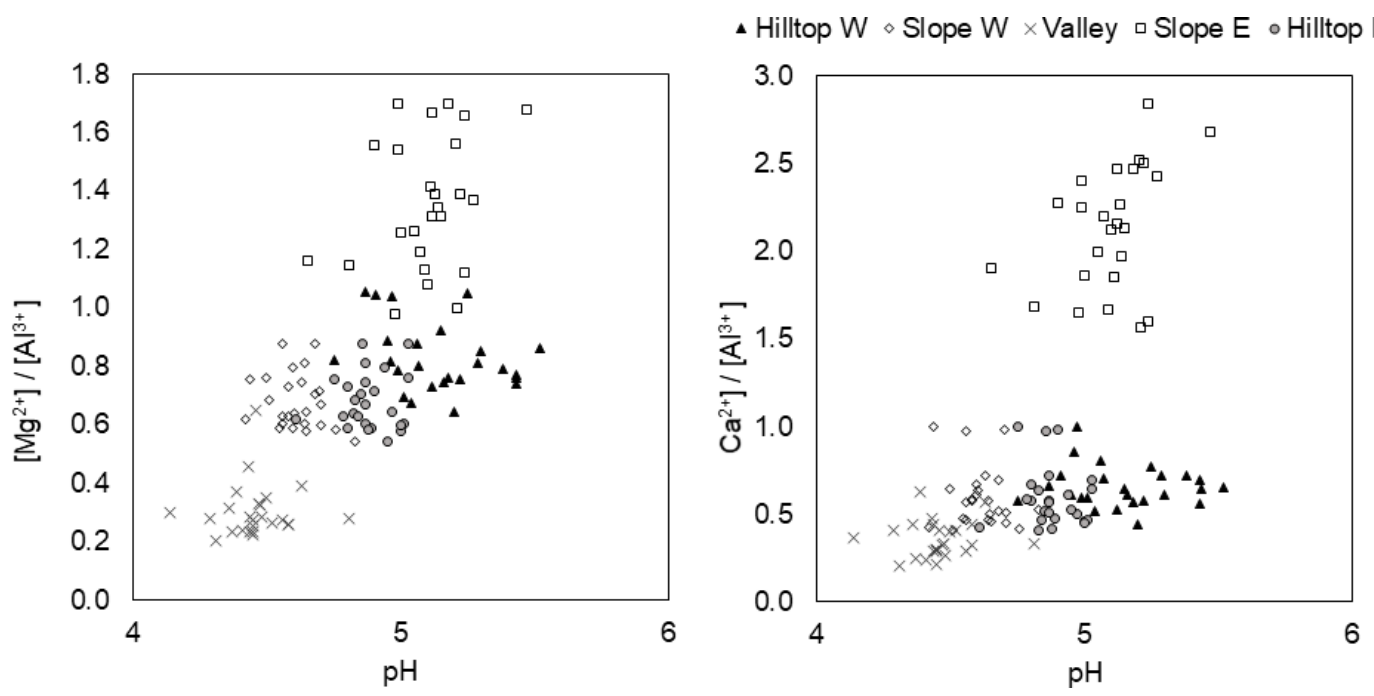

Figure 4. Comparison of $\mathrm{Ca} / \mathrm{Al}$ and $\mathrm{Mg} / \mathrm{Al}$ vs. $\mathrm{pH}$.

water", defined as the sum of all water pools and fluxes that respond to changing precipitation amounts. This mobile water transiently increases soil solution saturation and concomitantly with such an increase, the hydrologic connectivity of soil pore waters to the stream can cause a heterogeneous distribution of dissolved ions in soil solutions at the catchment scale (Basu et al., 2010).

Whilst factor analysis did not reveal significant relationships between measured UDL parameters (Fig. S2), the cross-plots in Fig. 4 show a relatively strong $\mathrm{pH}-\mathrm{Mg} / \mathrm{Al}$ correlation. Both variables in each cross-plot reached the highest values on slope east and the lowest values in the valley. Correlations seem to follow a spatial trend determined by the higher solubility of $\mathrm{Al}$ bearing minerals at lower $\mathrm{pH}$ (Palmer et al., 2005). Finally, given the complexity of the possible interrelations among the environmental variables considered here, there was an apparent generally poor correlation between solute concentrations measured in the soil in 20122013 and decadal runoff and atmospheric deposition data compiled in Table 1 (following Ouhlele et al., 2017). Such a result in turn points to a major control exerted over the soil solution chemistry by both groundwater-carrying legacy pollutants and spatially variable soil organic and inorganic ligand contents that likely determines the residence time of each of the measured components.

\subsection{Phosphorus availability and belowground C allocation}

Soil $\mathrm{P}$ sorption saturation is often used as an environmental indicator of soil $\mathrm{P}$ availability to runoff. Phosphorus losses from soils not subjected to an augmented erosional process are generally small (see Heuck and Spohn, 2016), with several factors determining which fractions are transported in streams. Among them hill slopes, climate and soil type fea- tures are the most relevant determinants of the preferential transport of mainly fine-size fractions and associated elements, such as $\mathrm{P}$ typically associated with $\mathrm{Al}$ - and (to a minor extent in UDL) Fe-(oxyhydr)oxide fractions (Borovec and Jan, 2018, and references therein). Our calculation of P sorbed by the soil particles, as determined by oxalate extraction, shows that between 22 and $29 \mathrm{mg}$ of P per kilogram of soil was sorbed at $40-80 \mathrm{~cm}$ depth at the time of sampling, with insignificant difference between hilltops, slopes and valley. It is possible that $\mathrm{P}$ limitation has developed because of the legacy of anthropogenic $\mathrm{N}$ deposition in this region. The homogenous pattern of low $\mathrm{P}$ availability contrasts with elevational differences in DOC concentrations in soil solutions (Fig. S1), which points to variable belowground leaching and allocation of $\mathrm{C}$ or could be reflective of variable inputs of $\mathrm{C}$ from regenerating vegetation in the $\mathrm{N}$-saturated, P-limited forest ecosystem. Conifer tree species are generally more tolerant to $\mathrm{P}$ limitations, which in turn make them more susceptible to nutrient depletion following losses from harvesting and exacerbated rates of nutrient export (Hume et al., 2018). We attribute the variable belowground allocation of $\mathrm{C}$ in UDL to spatially variable $\mathrm{Mg}^{2+}$ and/or $\mathrm{K}^{+}$deficiencies (e.g., Rosenstock et al., 2016) rather than to $\mathrm{P}$ imbalances within the catchment since we detected no spatially contrasting $\mathrm{P}$ deficiencies exerting influence over the contrasting patterns of nutrient limitation and subsoil nutrients leaching observed across the studied forested landscape.

\section{Conclusions}

The hydrochemical comparisons implemented here were aimed at evaluating spatial and temporal concentration patterns on the water chemistry among the subsoil compartment of the critical zone in a temperate forest. Because of 
landscape and lithological simplicity, which facilitates discerning flow paths without variability effects introduced by differential bedrock weathering, it was possible to discuss which factors in association with soil $\mathrm{N}$ saturation affect the soil solution chemistries of a small mountainous catchment area reforested by Norway spruce after acidification-related spruce die-back. By combining soil solution chemical measurements and establishing comparisons with published hydrochemical data, this work provides evidence pointing to substrate variability, and $\mathrm{C}$, but not $\mathrm{P}$ bioavailability, as major controls over the flux of base metal leached into the subsoil level and across the elevation gradient. Soil solutions at the $50 \mathrm{~cm}$ depth were generally more diluted than stream waters due to lateral surface runoff of solutions originating in the litter and humus enriched in $\mathrm{SO}_{4}^{2-}, \mathrm{NO}_{3}^{-}, \mathrm{K}^{+}, \mathrm{Na}^{+}$, $\mathrm{Ca}^{2+}$, and $\mathrm{Mg}^{2+}$. Increased concentrations are linked to anthropogenic atmosphere-derived pollution affecting natural (bio)geochemical processes. Differences between the chemistry of soil solution and runoff could also have been caused by a direct contribution of throughfall, with scavenged atmospheric chemicals from the canopy and leached nutrients from inside the foliage, or by polluted open-area precipitation. Soil solutions had lower $\mathrm{pH}$ in the valley than at upslope locations, being more diluted in the valley than on hilltops in the case of DOC, $\mathrm{Ca}^{2+}$ and $\mathrm{Mg}^{2+}$. Both $\mathrm{NO}_{3}^{-}$and $\mathrm{SO}_{4}^{2-}$ in soil solutions exhibited a clear seasonality that can affect base metal leaching, with maximum concentrations in the growing and dormant season, respectively.
The observed temporal trends amongst strong anion inputs and leaching of base metals and acid anions reflect that at the time of sampling nutrient imbalances in UDL were linked to groundwater carrying legacy pollutants. Complementary isotope modelling show that the responses of the studied mountain catchment to precipitation are fast, i.e., within the monthly sampling interval, with direct precipitation contributing $20 \%$ to $40 \%$ of the discharge and the rest being the contribution of local groundwater. When evaluated with regard to stream water chemistries and previously published input and fluxes, the dataset in this study provides insights into the localized controls and effects of acidification disturbances at the catchment scale and offers a perspective of the spatially and temporarily variable nutrient concentrations in soil solutions that is relevant for (i) more effectively designing stream water chemical analyses aimed at understanding the coupling of soil development processes and hydrology over variable timescales, and between deep and shallow weathering processes in mountain catchments; and (ii) for evaluating soil recovery processes after atmospherically induced perturbations that affected other catchments analogue to UDL.

Data availability. The raw data can be requested from Daniel A. Petrash (daniel.petras@geology.cz) at the Czech Geological Survey. 
Appendix A: Hydraulic insights from ${ }^{18} \mathrm{O} /{ }^{16} \mathrm{O}$ isotope modelling
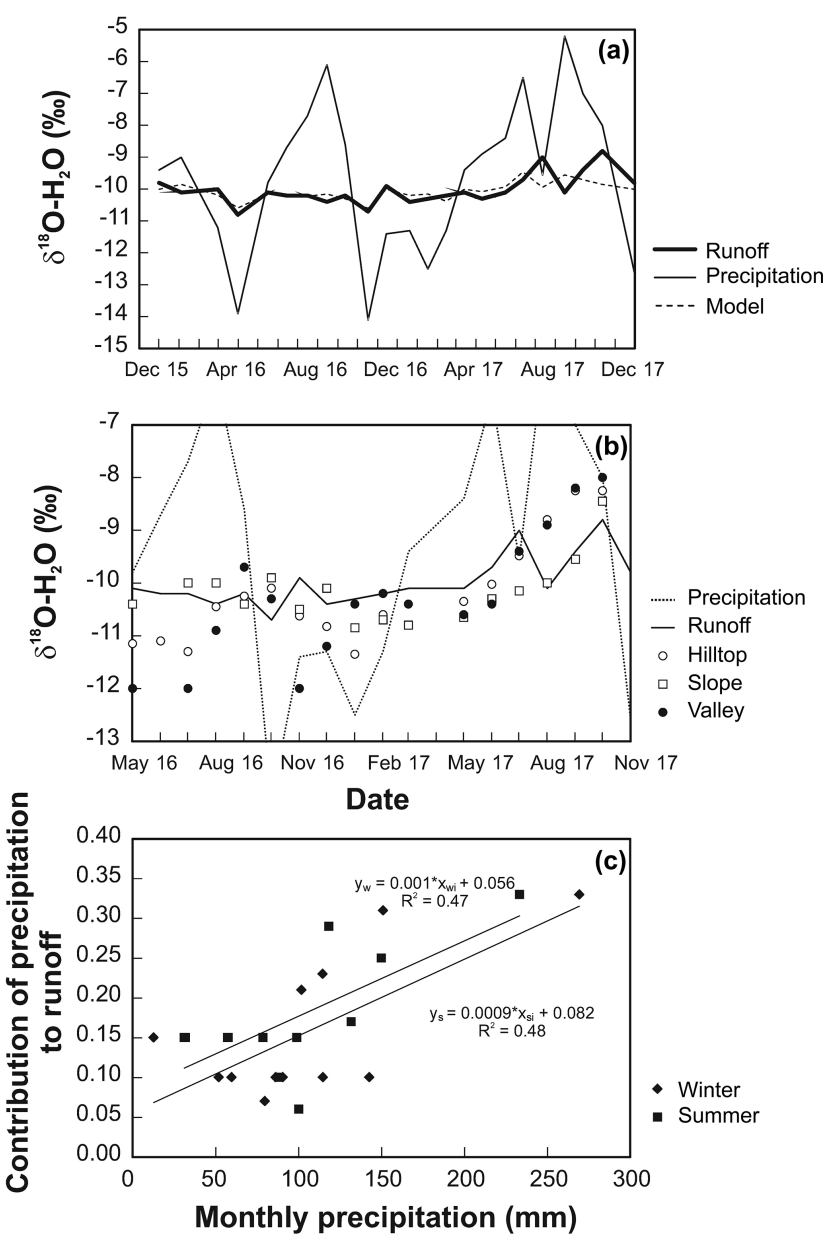

Figure A1. Time series of $\delta^{18} \mathrm{O}$ : (a) input-output model; (b) areal distribution across the UDL catchment; (c) estimated contribution of precipitation in runoff.

Aimed at constraining the hydraulic parameters of the catchment under evaluation, a runoff generation model based on the water years 2016-2017, i.e., on a later time period, was constructed as we believe it compares to the soil solutions during 2012-2013. To constrain the limitation of this approach, monthly precipitation among these periods was compared. As seen in Fig. S3, annual precipitation measurements are comparable, with totals $1236,1388,1110$, and $1284 \mathrm{~mm}$ in the hydrological years 2012, 2013, 2016, and 2017 , respectively. Precipitation in the driest year 2016 corresponded to $80 \%$ of precipitation in the wettest year 2013 . Across this period, the mean monthly precipitation consistently peaked in December, May, and September. Methodological details and mathematical components used to construct the isotopic ${ }^{18} \mathrm{O} /{ }^{16} \mathrm{O}$ model are provided in Appendix B (below).
Figure A1a shows that the $\delta^{18} \mathrm{O}$ values of atmospheric input did not follow a canonical sinusoidal curve isotopically heavy rainfall $\mathrm{O}$ in summer and isotopically light rainfall $\mathrm{O}$ in winter. Isotopically lighter $\mathrm{H}_{2} \mathrm{O}-\mathrm{O}$ in soil solutions relative to runoff in the spring of both years (Fig. A1b) indicates that water derived from the snowmelt predominates in soil pores several months toward summer. Isotopically heavier $\mathrm{H}_{2} \mathrm{O}-\mathrm{O}$ in soil solution, common in summer of the first year and in autumn of the second year, more closely corresponded to high $\delta^{18} \mathrm{O}$ values of the instantaneous precipitation. Interestingly, $\delta^{18} \mathrm{O}$ values of soil solutions in the valley (solid circles in Fig. A1) often departed from $\delta^{18} \mathrm{O}$ values of runoff (thick solid line in Fig. A1b), despite the very small distance between the two sampling sites $(70 \mathrm{~m})$. Despite interpretative limitations imposed by different monitored periods, the runoff generation model can be generalized for the catchment interrogated here. Accordingly,

- The response of the within-catchment hydrological system to precipitation is fast.

- The hydrochemistry at the $5 \mathrm{~cm}$ soil depth reflected preceding precipitation events, modified by evapotranspiration and, to a much smaller extent, mineral dissolution; the mixture mostly remained in soil pores until saturation was reached and leaching initiated; cf. Siegenthaler (1979).

- The contribution of bulk precipitation to runoff is relatively low: $5 \%$ to $35 \%$ (Fig. A1c).

The mean residence time of water in the UDL catchment ( $\sim 8.3$ months) was shorter than in three previously studied catchments in the Czech Republic. Lysina (LYS) catchment in the western Czech Republic (elevation of 830-950 m) was characterized by a mean water residence time of 15.2 months (Buzek et al., 2009). Dehtare and Jenin catchments in the central Czech Republic (elevations of 500-640 and 640$880 \mathrm{~m}$ ) had a mean water residence time of 12.5 and 9.3 months, respectively (Buzek et al., 1995). A fourth small catchment located in a spruce die-back affected area near Jezeri (north-western Czech Republic; elevation of 540-750 m) exhibited just a slightly lower mean water residence time of 7.2 months than UDL (Maloszewski and Zuber, 1982). While the bedrock at Jezeri and UDL was similar (gneiss), the steepness of both catchments differed (elevational span of $210 \mathrm{~m}$ at Jezeri vs. mere $70 \mathrm{~m}$ at UDL). The mean residence time of water at Jezeri and UDL was similar despite contrasting catchment areas ( 2.6 vs. $0.3 \mathrm{~km}^{2}$ ).

\section{Appendix B: $O$ isotope analyses}

Atmospheric deposition was sampled in an open area ("rainfall"). Cumulative monthly rainfall was collected in three replicates, $20 \mathrm{~m}$ apart, $1.2 \mathrm{~m}$ above ground. Diffusive and evaporative losses from narrow-mouth rain collectors were 
avoided by keeping precipitation under a $5 \mathrm{~mm}$ layer of chemically stable mineral oil. Grab samples of runoff were collected monthly at the closing profile. The $\delta^{18} \mathrm{O}_{\mathrm{H}_{2} \mathrm{O}}$ values were obtained by off-axis integrated cavity output spectroscopy (OA-ICOS; Liquid Water Isotope Analyzer, Model 3000, LGR Inc., Mountain View, Ca, USA). One $\mu \mathrm{L}$ of water was injected through a port heated to $80^{\circ} \mathrm{C}$. The vapor was transported into a pre-evacuated cavity and analyzed for the ${ }^{18} \mathrm{O} /{ }^{16} \mathrm{O}$ ratio. The reproducibility of $\delta^{18} \mathrm{O}_{\mathrm{H}_{2} \mathrm{O}}$ determinations was better than $0.20 \%$.

\section{$\delta^{18} \mathrm{O}_{\mathrm{H}_{2} \mathrm{O}}$ modelling approach}

A two-component model of runoff generation was produced using oxygen isotope ratios of $\mathrm{H}_{2} \mathrm{O}\left(\delta^{18} \mathrm{O}_{\mathrm{H}_{2} \mathrm{O}}\right)$ of open-area precipitation, runoff, and suction lysimeter water. The model is derived from a general isotope mass balance calculated following Eq. (1):

$\delta^{18} \mathrm{O}_{\mathrm{tot}}=\frac{\sum \delta^{18} \mathrm{O}_{\mathrm{i}} \cdot Q_{\mathrm{i}}}{Q_{\mathrm{tot}}}[\%$ o $]$,

where $i$ is an individual water source, $Q_{\mathrm{i}}$ is its mass flow $\left(\mathrm{m}^{3}\right)$ and $Q_{\text {tot }}$ is the total flow $\left(\mathrm{m}^{3}\right)$. This mass balance is typically used for the separation of stormflow hydrograph into its event and pre-event components (Eq. 2):

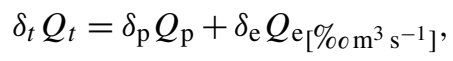

where $Q_{t}$ is streamflow $\left(\mathrm{m}^{3} \mathrm{~s}^{-1}\right), Q_{\mathrm{p}}$ and $Q_{\mathrm{e}}$ are contributing pre-event water (groundwater) and event water (rainfall, snowmelt) $\left(\mathrm{m}^{3} \mathrm{~s}^{-1}\right)$, and $\delta_{t}, \delta_{\mathrm{p}}$, and $\delta_{\mathrm{e}}$ are the corresponding isotopic compositions (\%o). Equation (2) can be solved parametrically for the contribution of the event water $p$ and of the pre-event water $1-p$ as shown in Eq. (3):

$p=\frac{Q_{\mathrm{e}}}{Q_{t}}=\frac{\delta_{t}-\delta_{\mathrm{p}}}{\delta_{\mathrm{e}}-\delta_{\mathrm{p}}}$
The mass balance (Eq. B1) is valid for any period of time if the isotope composition of all the components is known, for example for winter and summer. The mean annual $\delta^{18} \mathrm{O}$ isotope composition (mean groundwater input), $\delta_{\text {in }}$, was estimated as the mean $\delta^{18} \mathrm{O}_{\text {tot }}$ of the runoff.

A simple method of estimating the turnover time (mean age) of the subsurface reservoir employs an exponential model approximation; the distribution of transit times of water in the outflow is exponential and likely corresponds to permeability decreasing with the aquifer depth (Maloszewski and Zuber, 1982; Buzek, 1991). In case of stable isotopes, Siegenthaler (1979) demonstrated that the input (i.e., precipitation) can be approximated by a sinusoidal function with a 1 -year period as per Eq. (4):

$\delta_{\text {precip }}=D+A \sin (2 \delta t)$,

where $D=$ constant, $A=$ amplitude of $\delta^{18} \mathrm{O}$ variation in precipitation, $t$ takes values $0-1$ for a full-year period. Under a simplifying assumption of constant filtration and discharge, this input appears in discharge from the system as approximated by the factor $B / A$ (Eq. 5 ):

$\delta_{\text {discharge }}=D+B \sin (2 \delta t+\delta)$,

where $B$ is the amplitude of $\delta^{18} \mathrm{O}$ variation in output (discharge) a $\delta$ is the time shift of output variations in relation to input. The mean transit time $(T)$ in years can be determined using Eq. (6), either the damping factor $B / A$ or the phase shift $\delta$ :

$T=1 / 2 \delta\left((B / A)^{-2}-1\right)^{1 / 2}$.

A similar approach can be applied also to lysimeters; $\delta_{\text {precip }}$ represents the input, and infiltrated soil solution $\left(\delta_{\text {inf }}\right)$ is used instead of $\delta_{\text {discharge }}$. 
Supplement. Fig. S1: descriptive statistics (2012-2013) for soil solution concentration values of dissolved organic carbon, sulfate, nitrate, base cations, aluminum and chloride (in $\mathrm{mg} \mathrm{L}^{-1}$ ) and $\mathrm{pH}$ values at $50 \mathrm{~cm}$ depth at UDL; Fig. S2: non-parametric multidimensional scaling ordination of time-series hydrochemical data for stream water, rainwater and soil solutions collected in lysimeters; Fig. S3: comparison of monthly precipitation volumes at UDL during the monitoring period (2012-2013) vs. the hydrologic years 2016-2017. Table S1: coefficient of variation $\left(C_{\mathrm{V}}=100 \sigma / \mu\right)$ of inorganic species across our lysimeter network. The supplement related to this article is available online at: https://doi.org/10.5194/soil-5-205-2019-supplement.

Author contributions. Conceptualization was by MN, FB, and DAP, methodology by $\mathrm{MN}$ and $\mathrm{FB}$, data acquisition/validation by JC, FV, BC, JC, TC, OM, FV, and LB, visualization by MS, formal analysis and investigation by DAP and $\mathrm{PH}$, writing and original draft preparation by $\mathrm{DP}, \mathrm{MN}, \mathrm{PH}$, and $\mathrm{PK}$, and writing, review, and editing by DAP, PK, and MN.

Competing interests. The authors declare that they have no conflict of interest.

Acknowledgements. We express our gratitude to Laure Soucémarianadin and two anonymous reviewers for valuable suggestions and thoughtful criticism that greatly improved the quality of this paper. Jakub Hruska and Tomas Navratil provided liming maps of the Eagle Mts. and data on oxalate extractions, respectively. We are grateful to Filip Oulehle for providing input-output hydrochemical data and his constructive criticism of an earlier version of the manuscript.

Financial support. This research has been supported by the Czech Science Foundation (GACR) (grant no. 18-15498S).

Review statement. This paper was edited by Teodoro Miano and reviewed by two anonymous referees.

\section{References}

Aber, J. D., Nadelhoffer, K. J., Steudler, P., and Melillo, J. M.: Nitrogen saturation in northern forest ecosystems: excess nitrogen from fossil fuel combustion may stress the biosphere, Bioscience 39, 378-386, https://doi.org/10.2307/1311067, 1989.

Akselsson, C., Westling, O., Sverdrup, H., and Gundersen, P.: Nutrient and carbon budgets in forest soils as decision support in sustainable forest management, Forest Ecol. Manag., 238, 167174, 2007.

Akselsson, C., Westling, O., Alveteg, M., Thelin, G., Fransson, A. M., and Hellsten, S.: The influence of $\mathrm{N}$ load and harvest intensity on the risk of P limitation in Swedish forest soils, Sci. Total Environ., 404, 284-289, 2008.
Alewell, C.: Predicting Reversibility of Acidification: The European Sulfur Story, Water Air Soil Poll., 130, 1271-1276, 2001.

Armbruster, M., Abiy, M., and Feger, K. H.: The biogeochemistry of two forested catchments in the Black Forest and the eastern Ore Mountains (Germany), Biogeochemisty, 65, 341-368, 2003.

Armbruster, M. and Feger, K.-H.: Temporal trends in the chemical composition of precipitation, soil seepage and stream water in two forested catchments in the Black Forest and the eastern Ore, Monit. Nat. Environ. 5, 129-148, 2004.

Basu, N. B, Destouni, G., Jawitz, J. W., Thompson, S. E., Loukinova, N. V., Darracq, A., Zanardo, S., Yaeger, M., Sivapalan, M., Rinaldo, A., and Rao, P. S. C.: Nutrient loads exported from managed catchments reveal emergent biogeochemical stationarity, Geoph. Res. Lett., 37, L23404, https://doi.org/10.1029/2010GL045168, 2010.

Beauchemin, S. and Simard, R. R.: Soil phosphorus saturation degree, review of some indices and their suitability for P management in Québec, Canada, Can. J. Soil Sci., 79, 615-625, 1999.

Blazkova, M.: Black Triangle - The Most Polluted Part of Central Europe, in: Regional Approaches to Water Pollution in the Environment, edited by: Rijtema P. E. and Elias, V., NATO ASI Series 2, Environment, Kluwer Academic Publishers, Dordrecht, the Netherlands, 20, 227-249, https://doi.org/10.1007/978-94-0090345-6_11, 1996.

Borovec, J. and Jan, J.: Approach for predicting $\mathrm{P}$ sorption/desorption behaviour of potentially eroded topsoil in watercourses, Sci. Total Environ., 624, 1316-1324, 2018.

Brantley, S. L., White, T., West, N., Williams, J. Z., Forsythe, B., Shapich, D., Kaye, J., Lin, H., Shi, Y., Kaye, M., and Herndon, E.: Susquehanna Shale Hills Critical Zone Observatory, Shale Hills in the context of Shaver's Creek watershed, Vadose Zone J., 17, 180092, https://doi.org/10.2136/vzj2018.04.0092, 2018.

Buzek, F., Hanzlik, J., Hruby, M., and Tryzna, P.: Evaluation of the runoff components on the slope of an open-cast mine by means of environmental isotopes ${ }^{18} \mathrm{O}$ and T, J. Hydrol., 127, 23-36, 1991.

Buzek, F., Hruska, J., and Kram, P.: Three component model of runoff generation, Lysina catchment, Czech Republic, Water Air Soil Poll., 79, 391-408 1995.

Buzek, F., Bystricky, V., Kadlecova, R., Kvitek, T., Ondr, P., Sanda, M., Zajicek, A., and Zlabek, P.: Application of two-component model of drainage discharge to nitrate contamination, J. Contam. Hydrol., 106, 99-117, 2009.

CENIA: Zpráva o životním prostředí České republiky, Prague, Czech Republic, available at: https://www.cenia.cz/wp-content/uploads/2019/03/

Zprava-o-zivotnim-prostredi-Ceske-republiky_2017.pdf (last access: 5 May 2019), 2017.

Don, J., Skacel, J., and Gotowala, R.: The boundary zone of the East and West Sudetes on the 1:50000 scale geological map of the Velke Vrbno, Stare Mesto and Snieżnik Metamorphic Units, Geologia Sudetica 35, 25-59, 2003.

Galloway, J. N., Aber, J. D., Erisman, J. W., Seitzinger, S. P., Howarth, R. W., Cowling, E. B., and Cosby, B. J.: The nitrogen cascade, Bioscience, 53, 341-356, 2003.

Galloway, J. N., Townsend, J., Erisman, J. W., et al.: Transformation of the nitrogen cycle: Recent trends, questions, and potential solutions, Science, 320, https://doi.org/10.1126/science.1136674, 889-892, 2008. 
Godsey, S. E., Kirchner, J. W., and Clow, D. W.: Concentrationdischarge relationships reflect chemostatic characteristics of US catchments, Hydrol. Process., 23, 1844-1864, 2009.

Gradowski, T. and Thomas, S. C.: Responses of Acer saccharum canopy trees and samplings to $\mathrm{P}, \mathrm{K}$ and lime additions under high N deposition, Tree Physiol., 28, 173-185, 2008.

Gundersen, P., Schmidt, I. K., and Raulund-Rasmussen, K.: Leaching of nitrate from temperate forests effects of air pollution and forest management, Environ. Rev., 14, 1-57, 2006.

Heuck, C. and Spohn, M.: Carbon, nitrogen and phosphorus net mineralization in organic horizons of temperate forests, stoichiometry and relations to organic matter quality, Biogeochemistry, 131, 229-242, 2016.

Holmberg, M., Aherne, J., Austnes, K., Beloica, J., de Marco, A., Dirnböck, T., Fornasier, F., Goergen, K., Futter, M., Lindroos, A.-J., Kram, P., Neirynck, J., Pecka, T., Posch, M., Rowe, E., Scheuschner, T., Schlutow, A., Valinia, S., and Forsius, M.: Forest soil $\mathrm{C}, \mathrm{N}$ and $\mathrm{pH}$ response to $\mathrm{N}$ and $\mathrm{S}$ deposition and climate change a modelling study at European LTER sites, Sci. Total Environ., 640-641, 387-399, 2018.

Hruška, J. and Krám, P.: Modelling long-term changes in stream water and soil chemistry in catchments with contrasting vulnerability to acidification (Lysina and Pluhuv Bor, Czech Republic), Hydrol. Earth Syst. Sci., 7, 525-539, https://doi.org/10.5194/hess-7-525-2003, 2003.

Hruska, J., Cudlin, P., and Kram, P.: Relationship between Norway spruce status and soil solution base cations/aluminium ratios in the Czech Republic, Water, Air Soil Poll., 130, 983-988, 2001, 2001.

Hume, A. M., Chen, H. Y. H., and Taylor, A. R.: Intensive forest harvesting increases susceptibility of northern forest soils to carbon, nitrogen and phosphorus loss, J. Appl. Ecol., 55, 246-255, 2018.

Huntington, T. G., Ryan, D. F., and Hamburg, S. P.: Estimating soil nitrogen and carbon pools in a northern hardwood forest ecosystem, Soil Sci. Soc. Am. J., 52, 1162-1167, 1988.

Johnson, J., Graf Pannatier, E., Carnicelli, S., Cecchini, G., Clarke, N., Cools, N., Hansen, K., Meesenburg, H., Nieminen, T. M., Pihl-Karlsson, G., and Titeux, H.: The response of soil solution chemistry in European forests to decreasing acid deposition, Glob. Change Biol., 24, 3603-3619, 2018.

Kram, P., Hruska, J., Wenner, B. S., Driscoll, C. T., and Johnson, C. E.: The biogeochemistry of basic cations in two forest catchments with contrasting lithology in the Czech Republic, Biogeochemistry, 37, 173-202, 1997.

Kram, P., Hruska, J., and Bishop, K.: Monitoring and modeling of long-term changes of streamwater chemistry in two small catchments with contrasting vulnerability to acidification, UNESCO Technical Documents in Hydrology, 67, 197-202, 2003.

Kram, P., Hruska, J., and Shanley, J. B.: Streamwater chemistry in three contrasting monolithologic Czech catchments, Appl. Geochem., 27, 1854-1863, 2012.

Kolar, T., Cermak, P., Oulehle, F., Trnka, M., Stepanek, P., Cudlin, P., Hruska, J., Büntgen, U., and Rybnicek, M.: Pollution control enhanced spruce growth in the "Black Triangle" near the CzechPolish border, Sci. Total Environ., 538, 703-711, 2015.

Kopacek, J., Prochazkova, L., Stuchlik, E., and Blazka P.: The nitrogen phosphorus relationship in mountain lakes: influence of atmospheric input, watershed, and pH, Limnol. Oceanogr. 40, 930-937, 1995.

Kopacek, J., Hejzlar, J., Kram, P., Oulehle, F., and Posch, M.: Effect of industrial dust on precipitation chemistry in the Czech Republic Central Europe from 1850 to 2013, Water Res., 103, 30-43, 2015.

Lovett, G. and Goodale, C.: A new conceptual model of nitrogen saturation based on experimental nitrogen addition to an oak forest, Ecosystems, 14, 615-631, 2011.

MacDonald, J. A., Dise, N. B., Matzner, E., Armbruster, M., Gundersen, P., and Forsius, M.: Nitrogen input together with ecosystem nitrogen enrichment predict nitrate leaching from European forests, Global Change Biol. 8, 1028-1033, 2002.

Maloszewski, P. and Zuber, A.: Determining the turnover time of groundwater systems with the aid of environmental tracers, J. Hydrol., 573-574, 207-231, https://doi.org/10.1016/00221694(82)90147-0, 1982.

Manderscheid, B., Matzner, E., Meiwes, K. J., and Xu, Y.-J.: LongTerm Development of Element Budgets in a Norway spruce (Picea abies L. Karst) Forest of the German Solling Area, Water Air Soil Poll. 79, 3-18, 1995.

Manderscheid, B. and Matzner, E.: Spatial and Temporal Variation of Soil Solution Chemistry and Ion Fluxes through the Soil in a Mature Norway-Spruce (Picea abies L. Karst Stand), Biogeochemistry, 30, 99-114, 1995.

Matschullat, J., Andreae, H., Lessmann, D., and Malessa, V. S. U.: Catchment acidification from the top down, Environ. Pollut., 77, 143-150, 1992.

Mayer, B., Prietzel, J., and Krouse, H. R.: The influence of sulfur deposition rates on sulfate retention patterns and mechanisms in aerated forest soils, Appl. Geochem., 16, 1003-1019, https://doi.org/10.1016/S0883-2927(01)00010-5, 2001.

McDowell, W. H., Magill, A. H., Aitkenhead-Peterson, J. A., Aber, J. D., Merriam, J. L., and Kaushal, S. S.: Effects of chronic nitrogen amendment on dissolved organic matter and inorganic nitrogen in soil solution, Forest Ecol. Manag., 196, 29-41, 2004.

McIntosh, J. C., Schaumberg, C., Perdrial, J., Harpold, A., Vázquez-Ortega, A., Rasmussen, C., Vinson, D., Zapata-Rios, X., Brooks, P. D., Meixner, T., Pelletier, J., Derry, L., and Chorover, J.: Geochemical evolution of the Critical Zone across variable time scales informs concentration-discharge relationships: Jemez River Basin Critical Zone Observatory, Water Resour. Res., 53, 4169-4196, 2017.

Monteith, D. T., Stoddard, J. L., Evans, C. D., de Wit, H. A., Forsius, M., Høgåsen, T., Wilander, A., Skjelkvåle, B. L., Jeffries, D. S., Vuorenmaa, J., and Keller, B.: Dissolved organic carbon trends resulting from changes in atmospheric deposition chemistry, Nature, 450, 537-540, 2007.

Moore, J., Lichtner, P. C., White, A. F., and Brantley, S. L.: Using a reactive transport model to elucidate differences between laboratory and field dissolution rates in regolith, Geochim. Cosmochim. Ac., 93, 235-261, 2012.

Mörth, C.-M., Torssander, P., Kjønaas, O. J., Stuanes, A. O., Moldan, F., and Giesler, R.: Mineralization of organic sulfur delays recovery from anthropogenic acidification, Environ. Sci. Technol. 39, 5234-5240, 2005.

Navratil, T., Kurz, D., Kram, P., Hofmeister, J., and Hruska, $\mathrm{J}$ : Acidification and recovery of soil at a heavily impacted forest catchment (Lysina, Czech Republic) - SAFE 
modeling and field results, Ecol. Model., 205, 464-474, https://doi.org/10.1016/j.ecolmodel.2007.03.008, 2007.

Nieminen, T., De Vos, B., Cools, N., König, N., Fischer, R., Iost, S., Meesenburg, H., Nicolas, M., O’Dea, P., Cecchini, G., Ferretti, M., De La Cruz, A., Derome, K., and Lindroos, A. J.: Part XI: Soil solution collection and analysis, in: edited by: UNECE ICP Forests Programme Co-ordinating Centre, in: Manual on methods and criteria for harmonized sampling, assessment, monitoring and analysis of the effects of air pollution on forests, Thunen Institute of Forest Ecosystems, Eberswalde, Germany, 2016.

Novak, M., Kirchner, J. W., Groscheova, H., Havel, M., Cerný, J., Krejčc, R., and Buzek, F.: Sulfur isotope dynamics in two Central European watersheds affected by high atmospheric deposition of SOx, Geochim. Cosmochim. Ac., 64, 367-383, https://doi.org/10.1016/0022-1694(82)90147-0, 2000.

Novak, M., Jackova, I., and Prechova, E.: Temporal trends in the isotope signature of air-borne sulfur in Central Europe, Environ. Sci. Technol., 35, 255-260, https://doi.org/10.1021/es0000753, 2001

Novak, M., Kirchner, J. W., Fottova, D., Prechova, E., Jackova, I., Kram, P., and Hruska, J.: Isotopic evidence for processes of sulfur retention/release in 13 forested catchments spanning a strong pollution gradient Czech Republic, central Europe, Global Biogeochem. Cy., 19, GB4012, https://doi.org/10.1029/2004GB002396, 2005.

Palmer, S. M., Wellington, B. I., Johnson, C. E., and Driscoll, C. T.: Landscape influences on aluminum and dissolved organic carbon in streams draining the Hubbard Brook valley, New Hampshire, USA, Hydrol. Process., 19, 1751-1769, 2005.

Perakis, S. S. and Hedin, L. O.: Nitrogen loss from unpolluted South American forests mainly via dissolved organic compounds, Nature, 415, 416-419, 2002.

Oulehle, F., Hofmeister, J., Cudlin, P., and Hruska, J: The effect of reduced atmospheric deposition on soil and soil solution chemistry at a site subjected to long-term acidification, Nacetin, Czech Republic, Sci. Total Environ., 370, 532-544, 2006.

Oulehle, F., Chuman, T., Hruska, J., Kram, P., McDowell, W.H., Myska, O., Navratil, T., Tesar, M.: Recovery from acidification alters concentrations and fluxes of solutes from Czech catchments, Biogeochemistry, 132, 251-272, 2017.

Rosenstock, N., Berner, C., Smits, M. M., Kram, P., and Wallander, H.: The role of phosphorus, magnesium and potassium availability in soil fungal exploration of mineral nutrient sources in Norway spruce forests, New Phytol., 211, 542-553, 2016.
Schoumans, O. F.: Determination of the degree of phosphate saturation in non-calcareous soils, in: Methods of Phosphorus Analysis in Soils, Sediments and Waters, edited by: Pierzynski, G. M., North Carolina State University, Raleigh, NC, USA, 31-34, 2000.

Scott, E. E. and Rothstein, D. E.: The dynamic exchange of dissolved organic matter percolating through six diverse soils, Soil Biol. Biochem., 69, 83-92, 2014.

Siegenthaler, U.: Stable hydrogen and oxygen isotopes in the water cycle, in: Lectures in Isotope Geology, edited by: Jager, E. and Hunzike, J. C., Springer-Verlag, Berlin, Germany, 264-273, 1979.

Smith, W. H.: Character and significance of forest tree root exudates, Ecology, 57, 324-331, 1976.

van Miegroet, H. and Cole, D. W.: The impact of nitrification on soil acidification and cation leaching in a red alder Alnus rubra ecosystem, J. Environ. Qual., 13, 586-590, 1984.

Verstraeten, A., Neirynck, J., Cools, N., Roskams, P., Louette, G., De Neve, S., and Sleutel, S.: Multiple nitrogen saturation indicators yield contradicting conclusions on improving nitrogen status of temperate forests, Ecol. Indic., 82, 451-462, 2017.

Vega, M., Pardo, R., Barrado, E., and Deban, L.: Assessment of seasonal and polluting effects on the quality of river water by exploratory data analysis, Water Res., 32, 3581-3592, 1998.

Waldner, P., Marchetto, A., Thimonier, A., Schmitt, M., Rogora, M., Granke, O., Mues, V., Hansen, K., Karlsson, G. P., Žlindra, D., and Clarke, N.: Detection of temporal trends in atmospheric deposition of inorganic nitrogen and sulphate to forests in Europe, Atmos. Environ., 95, 363-374, 2014.

Waldner, P., Thimonier, A., Graf Pannatier, E., Etzold, S., Schmitt, M., Marchetto, A., Rautio, P., Derome, K., Nieminen, T. M., Nevalainen, S., and Lindroos, A. J.: Exceedance of critical loads and of critical limits impacts tree nutrition across Europe, Ann. For. Sci., 72, 929-939, 2015.

Wesselink, L. G., Meiwes, K. J., Matzner, E., and Stein, A.: Longterm changes in water and soil chemistry in spruce and beech Forests, Solling, Germany, Environ, Sci. Technol., 29, 51-58, 1995.

Winchester, J. A., Pharaoh, T. C., and Verniers, J.: Palaeozoic amalgamation of Central Europe, Geol. Soc. Spec. Publ., 201, 237 277, 2002. 